\title{
73
}

.058

\section{A3 1922}

TO THE

\section{BOTANIC GARDENS,}

DOMINICA.

- (ILLUSTRATED.)

With an Index of the Principal Plants.

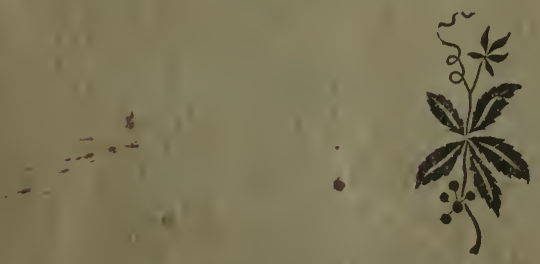

Price: One Shillings. 

orko

OFFICIAL GUTDE

TO THE

BOTANIC GARDENS,

DOMINICA.

crkos 




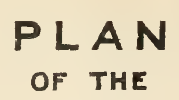

BOTANICAL GARDEN

\section{DOMINICA}

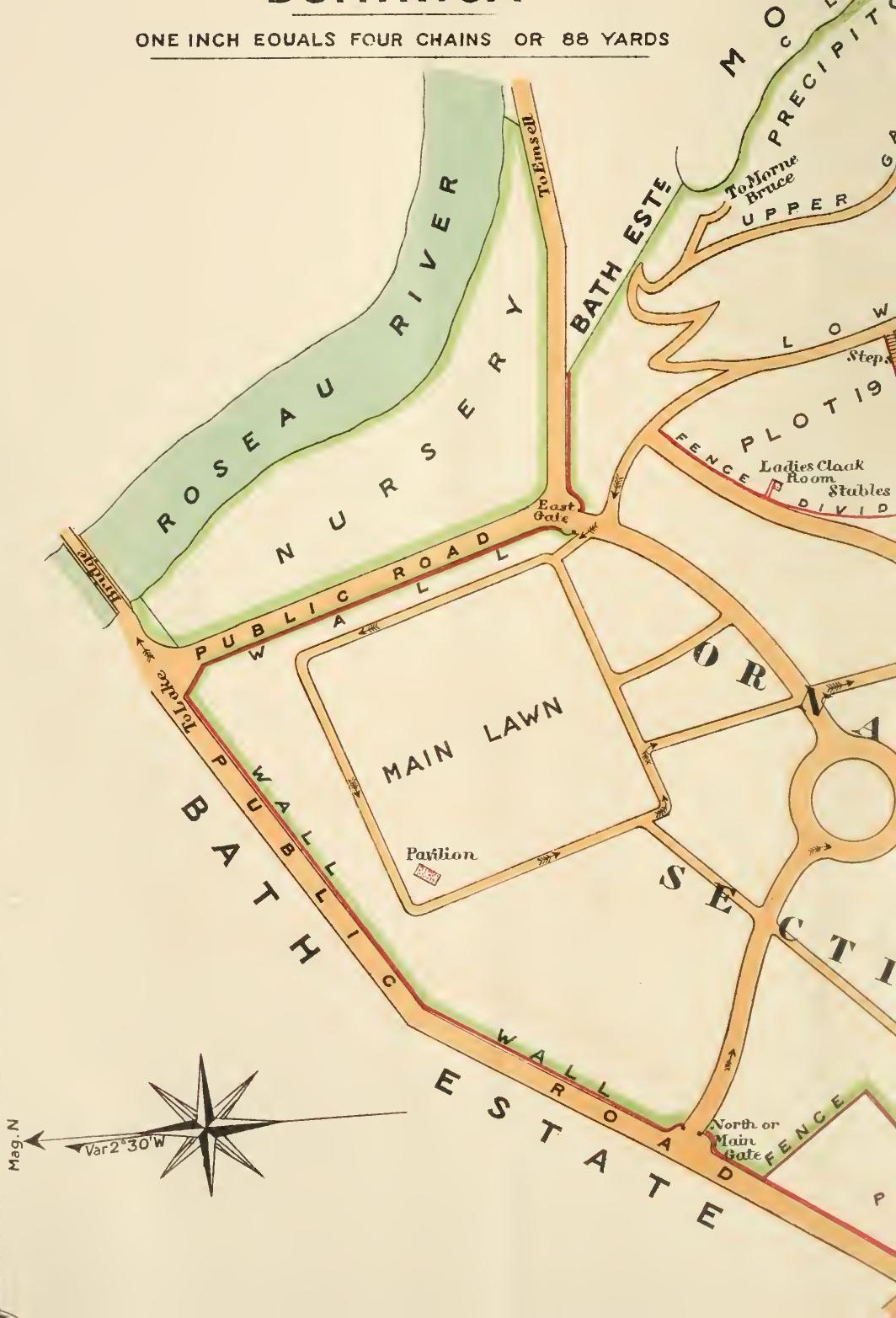




\section{OFFICIAL GUIDE TO THE BOTANIC GARDENS, DOMINICA.}

\section{INTRODUCTION.}

\section{HISTORY.}

The first steps towards the establishment of a Botanic Garden proper in Dominica were taken near the close of 1889 , and in January, 1891 the present site was purchased by the Government. Previous to this time a small nursery had been maintained in the grounds of Government House.

The first Curator in Dominica was Mr. Charles Murray, of the Edinburgh Botanic Gardens, who was appointed in September, 1889. He was transferred to Grenada in the following year, and succeeded by Mr. Henry F. Green in August, 1890. To Mr. Green fell the work of beginning the laying out of the grounds of the present garden. Mr. Green resigned in February, 1892, and was succeeded by the present Curator, Mr. Joseph Jones, of the Royal Gardens, Kew, who took up his duties in March, 1892.

\section{OBJECTS OF THE GARDEN.}

At the time the Garden was originally established, careful consideration was given to the purpose which it should serve, as will be seen from the following passages by Dr. (now Sir Daniel) Morris in the Kew Bulletin for 1891:

"Great stress has been laid on the objects in view in establishing this Botanical Station at Dominica. Its function has been defined as strictly of an experimental and economic character; ornamental plants are to be grown in moderate quantities for rendering the grounds attractive and interesting, but chief attention will, it is hoped, be devoted to plants of an economic or industrial character, and especially 
those likely to be in demand for establishing new plantations in Dominica. A list of such plants is given elsewhere. Again the more the cultural operations of every kind are carried on as object-lessons for the instruction of the people, th will the station fulfil its mission as an important factor in developing the resources of the island. The site is a most suitable one for a station, and it should prove in time one of the most interesting and attractive gardens in the whole of the West Indies."

\section{Situation AND Extent.}

The Garden lies immediately behind the town of Roseau, within ten minutes walk of the landing stage in the harbour. It is picturesquely situated in a hollow, under the precipitous Morne Bruce, on the top of which are old military buildings formerly occupied by the Agricultural School, an institution maintained for a period of eleven years, 1900 to 1911 , by the Imperial Department of Agriculture. The buildings are no longer used for the purposes of the school, the work of training agricultural pupils being now carried on at the Botanic Gardens under the supervision of the Botanic Gardens staff.

The area occupied by the Garden is some 44 acres. The land was originally a portion of the Bath Estate, and at the time of purchase was mainly under cane cultivation. The greater portion is of a gently undulating character, but the Garden includes the precipitous side of the Morne, the lower slopes only of which are suited for cultivation. The ground is very stony, and when taken over, a great part of the surface was covered with numerous long banks and heaps of stones which had been thrown aside during cane cultivation.

Immediately under the Norne is a hollow-sheltered from all winds except th south-west-where the deepest soil in the garden is located. This portion was selected for, and is now occupied by, a series of experiment plots. In the hurricane season, (August to October), damage has sometimes occurred in this portion from the strong south-westerly winds, which at times sweep along the hollow. A certain measure of protection is now given by a collection of trees and bamboos planted near to the southern boundary. The remainder of the Garden is well protected on all sides except to the north, 
but the boundary row of trees now affords a certain amount of protection from winds from this quarter. The most sheltered portion is along the lower slopes of the hill, and for this reason many of the valuable economic plants are placed along the lower hill path.

The Garden has an abundant water-supply from the Roseau reservoir, the mains of which to the town run through the middle of the Garden, and from which supplies for the nurseries are obtained.

Additions of Government land adjoining the Garden, and at Morne Bruce and in the Valley beyond, have been made from time to time for the purpose of citrus and rubber nurseries and experiment plots. The area of land worked by the Department is now close upon 80 acres.

\section{Climate and Rainfall.}

The climate is equable and moist. The average temperature fo: Roseau is about 79 degrees Fah., the average maximum being 84 degrees and the average minimum 75 degrees. February and March are the coolest months. The average yearly rainfall, from 1893 to 1920 was 77.58 inches; the maximum, occurring in 1915 (100.01 inches); and the minimum in $1900(53 \cdot 15)$. Taking the mean for twenty-seven years, April is the driest month and July the wettest. The early months of the year are, as a rule dry, the greatest amount of rain occurring in June, July, and August, whilst November and December are also usually fairly wet months.

While the early months of the year are the driest, coolest, and on the whele, best for tourists, the Garden at that time looks worst owing to lack of rain.

\section{Gejeril Features of the Vegetation.}

The general appearance of the vegetation of Dominica may be taken as typical of that of a tropical country in which conditions are sufficiently moist to permit of the luxuriant growth of trees. The greater part of the island, even to the summits of the highest mountains (about 4.700 feet) is covered with virgin forests. In striking contrast with the 
forests of temperate climates, they are evergreen. Certain trees may shed part or even all their leaves in the dry season, but they are the exception rather than the rule, and do not impair to any great extent the evergreen character of the forest'as a whole. The leaves of many of the trees are thick and leathery, fitting them to withstand the shortage of water in the dry season. In the lowlands, and in exposed situations the air is, comparatively speaking, dry; but in sheltered valleys, and along river courses, where the atmosphere is constantly saturated, the vegetation becomes still more luxuriant, the more tender shade and damp-loving tropical plants such as begonias, selaginellas and ferns, find congenial conditions, and we also see, well developed, one class of plants so characteristic of damp, tropical forests-the epiphytes. These are plants which find a lodgment on other trees, where they cling to the bark for mechanical support only, and depend for their existence on the rain which reaches them, and the nourishment they are able to extract from accumulations of humus and débris of various kinds, which collects about them. A conspicuous epiphytic flora, made up of mosses, lichens and algae, is also found in such conditions upon living leaves.

Although a little outside the scope of this guide-book, it may be of interest to point out that a ride from Roseau to the Waterfalls, for example, will give the visitor an excellent idea of how dependent the epiphytes and the more delicate tropical terrestrial plants are on the presence of an abundance of moisture in the air.

\section{ITINERARY.*}

Entrance Gates.

The Garden has three gates, situated approximately to the North, East, and South-west.

The northern gate is on the right hand side of the main road from town up to the valley of the Roseau River. It is the easiest gate to find from the town, and is in this Guide ealled the Main Gate.

* In following the itinerary as described, assistance will be derived by referring to the plan published with this Guide. 
The east gate is comparatively little used, opening as it does on to one of the country roads, the Emsall Road. It is spoken of later as the Emsall Gate.

The third gate, the south-western, is situated close to the cemetery, and lies behind the Cathedral. Although a little nearer to the town than the Main Gate, it is perhaps not quite so much used. From its proximity to the town it is here referred to as the Roseau Gate.

In the following itinerary it has been thought advisable to give first a description of the route from the Main Gate to the Curator's Office, and then to digress and describe the road from the Roseau Gate to the same place. Subsequently one common path is followed.

Visitors therefore who enter by the IIain Gate can use the book as it stands. Those who enter by the Roseau Gate should begin at page 16 .

\section{Main Gate to Curator's Office.}

The Main Gate, as already stated, is situated on the right hand side of the principal road from town up the Roseau Valley, some short distance before the bridge over the river. It may be found by going up Market Street, at the end of which the palms of the Garden will be seen, and the gate itself soon reached.

The lime estate on the left hand side of the road is the Bath Estate, where the limes used in the manufacture of Rose's Cordial are grown.

In addition to being the gate most directly accessible, this entrance gives the visitor the pleasantest first impression of the Garden. In front, and on either side as he enters, are well kept lawns, studded with trees. A green grassy drive runs up the gentle slope between two rows of Cabbage palms. A picturesque background to all is furnished by the wooded precipitous heights of Morne Bruce, and the more distant mountains over the Roseau Valley to the left.

On the gate posts is the handsome climber Bougainvillaea " Irs. Butt," other varieties of Bougainvillaea will be seen later. This plant is of interest inasmuch as it is not the 
flowers themselves that give it its showy appearance, but, as in the Poinsettias and some other plants, the leaves or bracts below the flowers. On either side of the gateway is a specimen of one of the handsomest of palms, Scheelea excelsa, closely allied to, and difficult to distinguish from, the Attaleas, in which genus it was formerly included.

Immediately behind the stone boundary wall on the left is a row of Acanthophoenix rubra, a handsome palm from Mauritius and Bourbon, and running parallel with it are a number of trees of Eucalyptus patentinervis, the Bastard Mahogany of Australia, a species recommended for park and street cultivation, on account of its leaves exhaling a pleasant odour. Near by is a fine group of Palms made up of twelve species.

Just inside the gate, and flanking the turfed road on either side, will be found: Berrya Ammonilla, a native of Ceylon, the Philippines, and Tropical Australia, noted for its timber, known as Trincomalee wood, and for the showy display made during the flowering and seeding period; Phoenix rupicola, an ornamental palm of the Himalayas region; and the gigantic fan-leaved Talipot Palm of Ceylon, Corypha umbraculifera.

Proceeding up the turfed road, the visitor passes between the rows of Cabbage palms, Oreodoxa oleracea, a native to the West Indies, and largely grown for ornamental purposes in the shape of avenues. Behind the Cabbage palms, on tre left hand side, are several trees of the whitewvod of Antigua, Terminalia Buceras, a very rapid growing tree furnishing a strong useful wood for general building purposes; also specimens of the Purging Cassia, Cassia Fistula, which bears clusters of handsome yellow flowers, and pods containing a sweet pulp which is used in the preparation of " confection of senna." The pods are exported on a small scale from Dominica. When young the pods are green, but woody and almost black when ripe. Apart from its economic value this tree is largely grown for ornamental purposes.

Along the boundary of the strip of lawn to the right will be found, in the following order: the "Yoruba Indigo" Lonchocarpus cyanescens; a fine specimen of Swietenia 
macrophylla, the source of Honduras mahogany; Lonchocarpus sericeus, native to Tropical America; Spathodea campanulata, a showy flowered tree of Western Tropical Africa; Premna odorata with agreeably scented leaves; Pterocarpus Rohrii; a fine specimen of Galba Calophylium Calaba, a native tree, known under the name of Santa Maria in Jamaica, of value for its timber, and also on account of its quick growth for wind belts; and the Candle berry tree Aleurites triloba, a native of Moluccas. In its native country the kernels of the fruit, when dried and stuck on a reed are used as a substitute for candles. The seeds taste like walnuts, and when pressed they yield a valuable oil. The root affords a brown dye.

Just before reaching the summit of the slight rise to the main drive, two avenues of palms, four rows deep, run right and left. The avenue to the left leads to the main lawn where cricket matches are played occasionally by permission of the authorities. The palms forming the avenues consist of miscellaneous species,--some planted singly, and others in small groups of half a dozen of a single species. The collection of palms in the neighbourhood numbers over thirty species, many of which are of great interest, including: Chrysalidocarpus lutescens, the bamboo palm from Madagascar; Areca Aliciae, an elegant palm from Tropical Australia; Latania Commersoni; and Hyophorbe amaricaulis, natives of Mauritius; Washingtonia filifera, a palm of South California ; the handsome Ptychoraphis augusta of the Nicobar Islands; Phoenix canariensis; and Thrinax parviflora, a native of the West Indies.

Proceeding along the road, two specimens of Alstonia scholaris, one on either side, will attract attention. This tree has a wide distribution throughout the tropics of the East, and yields a rubber, which, however, is difficult to prepare. The bark, known as " Dita Bark," is a valuable tonic.

The road here divides, running round a circle in the centre of which is a plant of one of the most graceful of the figs, Ficus Benjamina. This tree, though capable of spreading indefinitely, is restricted to the circle in which it stands, the diameter of the spread of the branches being about $1 \mathrm{CO}$ feet. 
Bearing to the right, several important economic and ornamental plants will be found along the edge of the lawn opposite the circle. The Yokewood or French Oak, Catalpa longissima, of Jamaica, Hayti, and St. Thomas, is worthy of special attention; it thrives well in the Gardens, and from an ornamental point of view serves a useful purpose in carrying and displaying to advantage Bougainvilleas, and other climbing plants of a similar habit. Catalpa longissima is easily recognised by its graceful habit, small lilac flowers, and long, almost thread-like pods. In Jamaica its wood is commonly used for boards and planks, and it is regarded as one of the best timber trees in that island. It is now naturalised in Dominica. Near by is a bed of a small native tree, Calliandra tergemina, known as Bois Ravine. This tree thrives best in dry situations, is very showy when in flower, and when properly treated is particularly useful as an ornamental hedge. Another valuable timber tree to be seen here is the Crabwood, Carapa guianensis, a native of Tropical America, and now introduced into several of the West Indian Islands. The seeds yield the intensely bitter Crab oil, also known as Andiroba oil, which is of value for warding off insect attacks.

Close by is the Flamboyante, Poinciana regia, introduced into the West Indies from Madagascar, and in great favour as an ornamental tree: its trusses of brilliant red flowers make a splendid show about June.

The turfed avenue at this point joins with the main drive, on the right hand side of which will be noticed a specimen of the Panama Candle tree, Parmentiera cerifera, so named from the resemblance of its fruits to the old fashioned dip candles. Almost opposite this tree is a clump of spiny palm, Bactris major.

On either side of the road is a clump of the dwarf Bambou of China and Japan, Bambusa nana. A fine specimen of Cassia emarginata, a tree with handsome foliage and conspicuous flowers, is growing near the clump of bamboo on the right ; a few yards away stands a tree of Cassia grandis, which, during the dry season, produces a wealth of flowers resembling apple blossom. At this point an avenue of mixed Caryota palms connects with the main carriage road. 


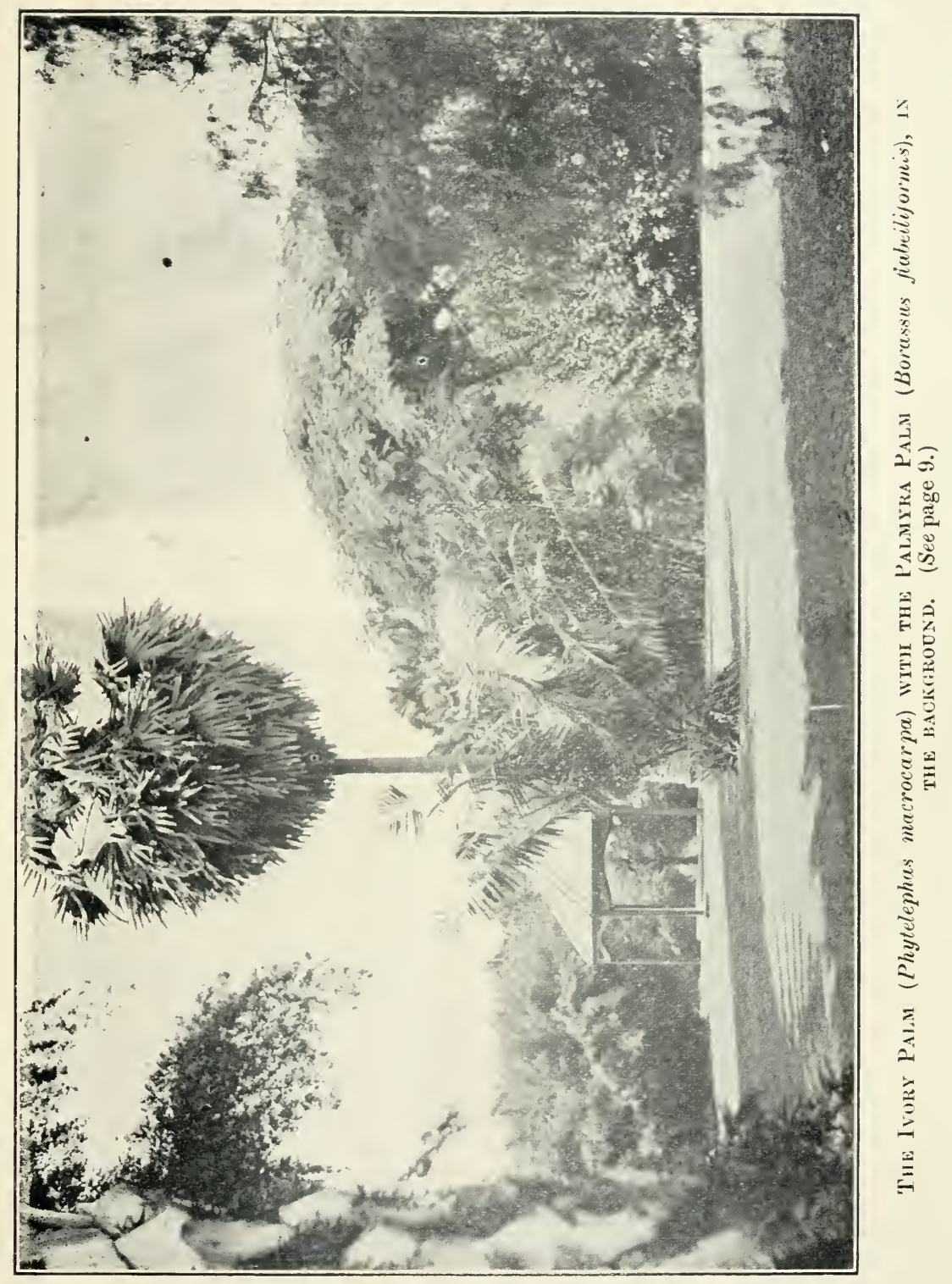



The species are: Caryota mitis, Caryota blancoi, and Caryota urens. The latter is a well-known palm of India and Ceylon. From its flower spikes a large quantity of juice called toddy or palm wine is obtained, and this when boiled yields palm sugar. A sago is prepared from the pithy part of the trunk. The fibre obtained from the leaf-stalks, called Kittul fibre, possesses great strength. Caryota palms on reaching maturity throw out a spike of flowers from the top of the tree, and after this has done flowering another comes out below it, and so on from each axil, until the palm is exhausted and dies.

On the lawn to the left, lying between the Caryota avenue and the circle, are two tall specimens of the Palmyra palm, Borassus flabelliformis, widely distributed throughout the tropical parts of Asia. The parts of this plant are applied to numerous uses by the Hindoos. A Tamil poem enumerates 801 uses, and does not exhaust the list. The sap or toddy obtained by tapping the flower spikes yields palm sugar. The young seedlings are cultivated in India and consumed as an article of food. Close by is Phytelephas macrocarpa, the Ivory palm which produces the vegetable ivory of commerce. Its native habitat is the banks of rivers in Central America. The fruits are borne in large globular heads. The seeds when ripe are very hard and are used for making knobs, coat buttons, chess-men, toys, etc. Some distance from the road are two clumps of bamboos: the graceful Thyrsostachys siamensis, and the Spiny Bamboo, Bambusa spinosa.

Immediately behind the fountain is a small specimen of the remarkable Bussu palm, Manicaria saccifera, native to parts of Central and South America, particularly the latter region where it inhabits the tidal swamps of the lower Amazon River. The leaves which are used by the natives for thatching purposes, and frequently measure as much as 30 feet in length, and 4 to 5 feet in width, differ from those of most other palms in that they remain entire: occasionally however, when old, they split irregularly. Close to this palm is a grass-like plant known as the Giant reed, Anundo Donax, native to the Mediterranean region, and largely cultivated in the Southern States of America and elsewhere as an ornamental plant. 
On the right-hand side of the main drive is a specimen of Cestrum diurnum, a small tree greatly valued for its fine display of sweet-scented white flowers; and further on a native tree known as Acoma St. Christophe, Sideroxylon floribundum, valued on account of its timber. Looking to the right across the lawn, which stretches in front of the Convent, a fine group of palms will be observed; and near by them a single specimen of Sapium sebiferum, which yields a tallow largely collected in China. The fruits, which contain the seeds enveloped in fat, are steamed, beaten, and sifted. The coarse tallow thus obtained is used by the Chinese for making candles. Large quantities of the tallow are imported into England for use in the manufacture of soap and candles.

Beyond the bed of palms, and in front of the Convent are specimens of Podocarpus sp.; Derris dalbergeoides; Sappan wood, Caesalpinia sappan, which furnishes a red dye-wood; Terminalia Arjuna; Mimusops Elengi, from the seeds of which an oil is expressed-the bark yielding a tonic and febrifuge; and Tecoma spectabilis, the latter being one of the well-known Poui tree of Trinidad, which for a few days in the dry season is a showy mass of bright yellow flowers.

Proceeding along the course of the carriage road, the following interesting plants will be found on the right: Ixora macrothyrsa; and Baikaea insignis, a tree of West Tropical Africa-probably the finest flowering tree in the Garden. The flowers are 10 inches across when fully expanded, and are remarkable as being the largest produced by any member of the Leguminoseae. The petals are snow white, except the lower petal or lip, which is lemon-yellow in colour. Also the Bead tree, Elaeocarpus Ganitrus, of India, where the hard stones of the fruit are commonly used for stringing into rosaries, or for making necklaces, bracelets, buttons, heads of pins, and similar articles.

Conspicuous amongst the plants here is a fine group of one of the Screw Pines, Pandanus utilis. The curious habit of this set of plants with their characteristic spirally arranged leaves and prop roots is well known. This particular species is a native of Madagascar, and is largely planted in Mauritius where its leaves are used for making sugar-bags. The dry eaves are used for making hats in Dominica. 
Further on is a bed of Dracaena Sanderiana; a fine specimen of Dalbergia lanceolaria; and at the corner of the plot of land which juts into the Garden is Terminalia Catappa, an East Indian plant now naturalised in the West Indies. This tree is valued for its timber; and the seeds, though destitute of flavour, are eaten as almonds. Climbing over this tree is a fine specimen of Bougainvillaea spectabilis.

On the small lawn to the right, behind the trees just mentioned, is a collection of trees and shrubs, and a small rockery containing a few species of Agave, Aloe, Furcraea, Sansevieria, Opuntia, Cereus, and other succulent plants. The interesting trees and shrubs on the lawn here are: Napoleona Miersii, which produces striking flowers; Hardwickia pinnata, and Dalbergia Sisso, two large handsome timber trees of India. The hard wood of the latter is used for boat building, gun-carriages, wheelwrights work, etc. The former yields a resin. Also note Afzclia madagascariensis, a particularly beautiful tree when making new growth, the young leaves being of a bright crimson colour; Copaifera officinalis, native of Tropical America, the source of "Balsam of Copaiba," an aloe-resin obtained from this and other species of Copaifera by making incisicns in the trunks; Limonia acidissima, a spiny shrub native of the East Indies; and the Ordeal Nut, Cerbera Tanghin, of Madagascar, so called on account of its poisonous fruits being at one time employed to de ide cases of suspected crime.

Other plants growing here are: Allamanda violacea; Gmelina Hystrix; Clerodendron Eastatum; Bougainvillaea fatuosa; and Russelna juncea, a showy dwarf plant of Mexico. Along the wall a row of palms, Chrysalidocarpus lutescens screens off this part of the Garden from the Public road.

Return now to the carriage drive near the group of Pandanus utilis, already mentioned, wher' will be found on the left-hand side, a small tree of Bois Tan, Byrsonima spicata, a native of $\mathrm{D}$ minica. The wood of this tree is tough, and light, and is made into beams, afters, posts, oars, etc.; the bark is us d for tanning. Apart from its alue as a source of timber and $t$ nnin, this tree, during the fl we ing and fruiting season, makes a showy display, and merits a place amon st other trees of a decorative kind. 
Immediately behind stands Melaleuca linarifolia, a native ofAustralia, whose graceful feathery foliage and creamy white flowers $m$ ke this tree a striking object of beauty for a lawn. Next, running parallel with the Caryota Avenue, and in line with the last named tree of Australia, is a specimen of a Brazilian palm, Astrocaryum Ayri. A little further on is the Marking Nut Tree, Semecarpus Anacardium, of India and Malaya, etc. The juice of the nut mixed with a little quicklime and water is used for marking linen ; undiluted it acts as a blister. The bark is used in dyeing.

Continuing along the carriage drive will be found the "Cannon Ball Tree," Couroupita guianensis, with its curious flowers and subsequent large woody fruits borne on the main stem; Norantea guianensis, which during the early months of the year makes a striking show with its long spikes of flowers with brilliant scarlet bracts; Butea frondosa, a showy flowered tree which yields Bengal Kino-a resin obtained by wounding the bark-of medicinal value as an astringent; the Balata tree of Dominica, Bumelia retusa, the timber of which is used for all kinds of mill work, and also for house work: this tree is sometimes referred to as the Bullet tree on account of the shape of its edible fruit. The tall erect tree close by is Sterculia alata, a native of India; immediately behind is a small group of palms of Thrinax Morrisii.

From this stretch of road a good view is obtainable of the hill-side beyond the experiment grounds. The lower slopes are cultivated in cacao, rubber, mangoes, etc., whilst the upper, almost precipitous, portion is covered with wild, mainly native, vegetation.

Some allusion may be made at this point to the more interesting of the native trees which flourish on the steep hill-side. Among them are the Coubaril, or Locust tree, Hymenaea Courbaril, whose valuable timber, known locally as native Nahogany, is used for making all kinds of furniture; Savonette, Lonchocarpus violaceus, a fine flowering tree which yields a hardwood used for various purposes; the Lowland Gomier, Bursera gummifera, whose branches when cut and placed in the ground grow readily and form live posts for fencing ; and the White Cedar or Poirier, Tabibuia leucoxylon, 


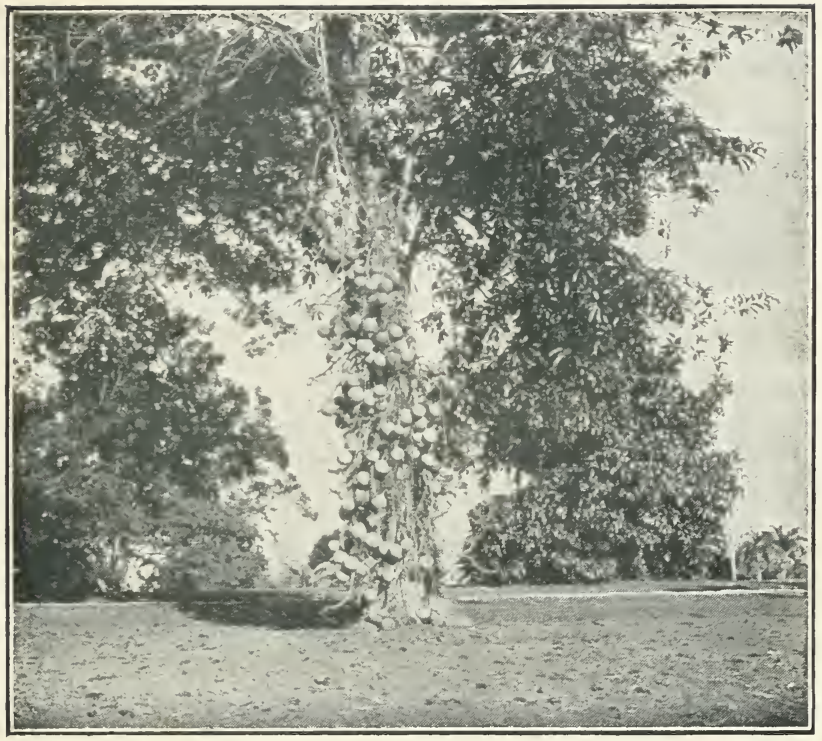

Caxom b.uLl Thes (Couroupita guianensis). (See page 12.) 

a useful timber employed for inside and outside work, for shipbuilding, and for piles and jetties, as it lasts well in sea-water.

Other interesting trees are Laurier Cypre, Cordia Gerascanthus, a fairly quick growing timber tree, the wood of which is used for a variety of purposes including furniture making; Bois Cotlette, Citharexylon quadrangulare, which yields a useful timber; Bois Chandelle, Amyris balsamifera, a small tree used for fosts and for making flambeaux; and Bois D'Orme, Guazuma ulmifolia.

Thevetia nerifolia, with glossy foliage and yellow flowers, which yields the "lucky seeds" so much in request for wearing as charms in the West Indies, is a plant of interest growing on the dry cliffs. Also Bois Vinette, Erythroxylon ovatum, a relation of the well-known Cocaine shrub, Erythroxylon Coca. The leaves of Bois Vinette contain only a small percentage of alkaloids compared with the amount yielded by the official plant E. Coca.

The Horse Tamarind, Lencaena glauca, a small tree largely grown in the Eastern tropics as a shade tree for coffee and other cultivations, for supplying mulch, and also for firewood, is to be found on this slope. In the West Indies owing to its persistence in and around cultivations, and the great difficulty and expense in exterminating it, this tree is generally regarded as an unmitigated pest.

Interspersed throughout this area are the common wayside flowering plant, Tecoma stans, which bears an abundance of yellow flowers; and Acacia riparia, a showy plant in the dry season, with its creamy white flowers.

Amongst the unidentified plants are several kinds of Mapou, Cordia spp., and Acoma Blanc, a fine tree, and probably an undescribed species.

Growing over and amongst the trees are numerous creepers, the most showy of which is Bignonia Unguis-cati. This creeper covers some of the large trees and makes a good display at the commencement of the wet season with its masses of large yellow flowers. The Baba-ou-le or Cap-la-hou, Dioscorea alata, is another climber much in evidence. Although an introduced yam-a useful food plant-it is now 
found in a wild state throughout the Island. After this little digression the visitor should continue along the main drive.

The main drive here runs parallel with a hedge of Negro Peach, Sarcocephalus esculentus, which screens off a piece of private land jutting into the Garden. Before the hedge of Negro Peach was planted, this piece of land, sold previous to the Government obtaining the site for the present Garden, marred considerably the grounds at this point.

Opposite this hedge and next to the tree of Sterculia alata already mentioned, is a tree of Jacaranda mimosaefolia, which bears a profusion of blue bell-shaped flowers on the young shoots, as well as on the older branches. A little further on is Peltophorum Linnaei, native of Jamaica, from which the orange-coloured dye-wood, known as Brazilleto wood is obtained; and the Malayan and Australian Cedrela Toona, the wood of which is largely used in Australia for all kinds of furniture and ornamental work.

A striking object close to the corner, on the opposite side of the road, is the Assam Rubber tree, Ficus elastica, with its large shiny leathery leaves and bright-red bud sheaths. In localities which suit this tree, it reaches 100 feet or more in height, and throws down from its branches thread-like roots, which on reaching the ground thicken enormously, finally perhaps, equalling, or even exceeding the main trunk in diameter. This tree is familiar to most visitors as the IndiaRubber tree so commonly grown as a decorative plant in England and elsewhere. Next is a fine tree of Ficus altissima from Tropical Asia, and behind on the lawn is Ficus Vogelii, a native of West Africa. These trees, along with other latex yielding trees, are not at the present time tapped to the same extent as formerly, the World's chief supply of rubber now being the Para, obtained from Hevea brasiliensis, a tree native of Brazil, and cultivated on a large scale in the Middle East. Over in the corner, behind the rubber trees, will be found: Dolichandrone platycalyx, a tree native of East Africa, with handsome yellow flowers; and Myroxylon sonsonatense, a relation of the tree yielding Balsam of Tolu, Myroxylon Toluifera. Behind these trees is a hedge of Duranta Plumieri, extending almost to the drive, where, at the corner, there is a specimen of Sterculia sp. 
A specimen of Barringtonia speciosa, a native of tropical Asia, stands near th corner on the opposite side of the road. This is usually one of the first plants to obtain a footing on newly formed coral islands, its fruit being well adapted to sea transport.

On the lawn behind the last named, and extending in front of the row of picket fencing, backed by a hedge of Aralia Guilfoylei, are several specimens of Catalpa longissima, which act as supports for Beaumontia grandiflora, a vigorous growing climber from the East Indies, remarkable for its large handsome white flowers; Callichlamys riparia, native of British Guiana, which bears annually large yellow flowers streaked with crimson; Cryptostegia grandiflora, a climbing shrub with showy pink flowers; Entada polystachya, an interesting native climber, and the well-known Purple Wreath, of the West Indies, Petrea volubilis. Near by may be seen a specimen of native Simaruba, Simaruba amara, which furnishes a bitter wood from which cups are made for holding water to produce a tonic draught, and also a root bark which is a bitter tonic ; Hirtella triandra, a small native forest tree known locally as "Icacque," the timber of which is used for inside and outside work; and Berrya Ammonilla, a native of the tropics of the Old World.

Between the Catalpa trees and the path is Artabotrys odoratissimus, a climber from the East with very sweetscented yellow flowers. The hooked flower stalks by which it climbs are interesting and well worth attention. Other plants to be noted are Cocos plumosa, a Brazilian palm; Pandanus luzonensis; Pandanus graminifolius; Quisqualis indica; and the Baobab tree, Adansonia digitata, native of Tropical Africa, which attains to an enormous size in its native habitat. Its leaves, bark, and fruits are put to many uses by the natives of that region. Also Chloroxylon Swietenia, an East Indian tree, the source of the well-known Satin wood of commerce, used largely for the backs of hairbrushes and for inlaying. It may be observed here, that the lawns on either side of the carriage road, from the Roseau Gate to Emsall Gate, are dotted with numerous beds of ornamental and flowering plants, among which may be noted several varieties of Crotons, various species of Acalypha, 
Bougainvillea, Allamanda, Hibis cus, Aralia, and Ixora, as well as beds of Euphorbia sp., Galphimia brasiliensis, Duranta Plumieri, and the chaste, sweet-scented double-flowered variety of Gardenia florida, and other interesting plants which are effective in appearance when grouped together.

It is now proposed, for the convenience of visitors entering by the Roseau Gate, to enumerate the plants in the order they would be met with in passing from that gate to our present position, the main route will then be followed from this point as continued on page 19.

\section{The Roseau Gate.}

The Roseau Gate is situated in the angle where the Gardens adjoin the Cemetery. The road outside, which skirts the Cemetery wall, leads to the road ascending the Morne.

The gate posts support two handsome climbers: the brick red Bougainvillea, Bougainvillaea laterita; and the "Rangoon " creeper, Quisqualis indica, the flowers of which are sweet-scented and of an orange-red colour. Immediately to the left is a good specimen of one of the Myrobalans, Terminalia belerica, a native of the East Indies, whence its woody fruits are exported in large quantities to be used in tanning processes.

The hedge row to the left was formerly composed of Cabbage palms and West Indian Cedar, Cedrela odorata, but the latter, with the exception of two fine specimens still remaining, were completely destroyed in the hurricane of 1916. The wood of this tree is light, durable, handsome and fragrant, and moreover is not attacked by insects. It is largely used for furniture, interior work, cigar boxes, etc. In place of the West Indian Cedar knocked out in the hurricane plants of the Bermuda or pencil cedar, Juniperus bermudiana, largely grown for the sake of its ornamental appearance, and for its timber used for making cedar pencils, are now planted alternately with the Cabbage palms. Single specimens displaying to advantage the graceful habit of the Pencil Cedar tree, and others planted in a group, will be observed on the 
lawn in the vicinity. Along the boundary wall is a hedge of Bois Ravine, Calliandra Tergemina, a small native tree of decorative value, particularly as an ornamental hedge.

Further along the drive will be found the Yokewood tree, Catalpa longissima. The climbing plant growing on its trunk is the beautiful crimson Bougainvillea, variety Mrs. Butt. Next is to be seen Dillenia indica, native of Ceylon, and Tropical Asia generally. The hard tough wood of this tree is used for making gun-stocks; the juicy fruit is eatable, but very acid. It is used by the natives in India in curries and for making jelly. Further on will be found Pandanus Sanderiana; and Kigelia pinnata, an African tree remarkable for its long stalked panicles of flowers, which hang down from the older branches, and for its large fruits often 2 feet in length, and from 5 to 8 inches broad. It is commonly known by the name of Sausage tree. The fruits are of no economic value. On the right, near the gate, is Phoenix humilis, var. Roebelini. Continuing along the fence will be found: Brownea coccmea, which bears dense heads of scarlet flowers ; Livistona olivaeformis, native to Java, which closely resembles Livistona chinensis, of China and Japan, a palm growing near by. On the iron fence is a plant of the Barbados Gooseberry, Pereskia aculeata, a native of the West Indies, where its fruits are used for making preserves. The ornamental grass behind the fence is Thysanoloena agrostis. Note also Pinus bahamensis, a handsome conifer of the Bahamas; and a large tree of Terminalia sp., on the trunk of which is growing Dendrobium caiceolaria, and the well-known Vanda teres. At the foot of this tree is a Stapelia, a member of a large genus of South African plants. The flowers possess a repulsive odour. Behind is the Gru Gru palm, Acrocomia sclerocarpa, a native of the West Indies; and a row of the graceful bamboo, Thyrsosiachys siamensis. In this corner is a small collection of various species of Agaves. Further on is a small West Indian tree Comocladia ilicifolia, and a stemless palm, Phoenix acaulis.

A path which leads to the economic plots here connects with the carriage road. On either side is a specimen of Arenga Engleri. A little further on is Encephalartos Hildebrantii, a member of the Cycadaceae. The interior of 
the trunk of this plant contains a spongy farinaceous pith, made use of by the Kaffirs as food, hence the name Kaffir Bread is applied to it. Near by are two specimens of Latania Loddigesii ; a tree of the White Mulberry, Morus alba, a plant useful in connection with the raising of silkworms; and a specimen of Eucalyptus creba, the narrow-leafed iron bark tree of New South Wales, the timber of which is used for railway sleepers, for wagons, piles and fence posts.

Proceeding along the road, a native tree, Swartzia grandiflora will be seen on the right. This is remarkable on account of its single-petalled yellow flowers. Next is Capparis ferruginea, a native of the West Indies and behind this a large tree of Sterculia foetida, over which the giant climber Anodendron paniculatum, is growing. Continuing along the border will be found the following trees and shrubs: Nerium Oleander; Bauthinia picta; Bauhinia tomentosa; Bauhinia Petersiana; Saraca indica; Brunfelsia americana; Jatropha multifida; Calliandra haematocephala; Thunbergia erecta; Ixora coccinea, and its variety lutea. The hedge behind the picket fencing is formed partly of Acalypha Wilkesiana, a ruddy foliage plant known as Burning Bush ; and partly of Bixa Orellana, the Roucou tree of Dominica. The Annatto of commerce, a dve used for silks, and for colouring butter and cheese, is prepared from the redcoloured pulp which covers the seeds of the last named plant. Formerly this dye was used in Dominica by the Caribs to paint their bodies.

Growing immediately behind the hedge of "Burning Bush " are clumps of Alpinia mutans, the stems of which may become of importance as a source of material for paper-making. Also a young plant Mauritia flexuosa, the Moriche palm, common on swampy lands along the great rivers of Tropical America.

Much of the soil of the lawn on the left is very poor, and only such plants thrive on it as are adapted to such conditions. Several of those to be seen here are plants characteristic of dry or even desert regions; for example, the large columnar Cactus: Cereus peruviamus; next to which is Cerus Napoleonis; and a little further away a round bed containing several specimens of the well-known Turks Head Cactus. 
Cactus Melocactus, a native to the IVest Indies. (In Dominica this plant is confined to the precipitous parts of the Leeward Coast-particularly near the village of Colihaut, where it is very plentiful.) Note also the succulent Euphorbias closely resembling the true Cacti in habit, though belonging to a widely separated family of plants; and the striking Agave Franzosinii, a native of Mexico. Representatives of the handsome Bahamas pine, Pimus bahamensis ; the long-leaved pine, $P$. longifolia; and $P$. sinensis, may here be observed; as well as specimens of Cupressus glabra, a particularly fine conifer, which appears to flourish under tropical conditions; Araucaria Bidroillii and Araucaria brasiliensis. The habitats of the two trees last mentioned are widely separated : the former being a native of Australia, where the large seeds, contained in the cones attaining to the size of a man's head, are eaten as food by the aborigines; and the latter a native of Brazil, where it forms large forests. A group of plants which have existed from very distant geological times, namely, the Cycads, are represented here by Cycas Seemanii, and Zamia sp. The latter yields a starch, and is a native of San Domingo, where it covers large areas of land.

These plants, which so strikingly resemble tree ferns in their mode of growth, belong to the Gymnosperms, a group which includes also the Pines and Cypresses.

To complete the enumeration of the more important plants on this lawn mention must be made of the West African fruit tree, Chrysophyllum Milleni growing near the edge of the drive; and a bed of the white Hibiscus, $H$. Waimeae. The striking Pandanus on the lawn is $P$. pacificus.

Opposite the Assam Rubber tree is a path which we will now follow. On the right-hand of the path is an extremely fine specimen of the graceful African Locust tree, Parkia africana, and immediately behind it is the Negro Peach, Sarcocephalus esculentus, and its Asiatic ally, Sarcocephahus cordatus. Growing on the trunk of the latter is Piper longum, a plant much cultivated in India for the sake of its flowerstalks, which are collected when green and unripe, and when dried are known as Indian long pepper. This product is largely used by the natives of India as a spice, and in medicine. On the left-hand side of the path is a tall specimen of the 
Bloodwood tree, Eucalyptus corymbosa, of New South Wales, which yields a valuable timber. On the opposite side is a handsome evergreen tree, Elaeodendron glaucum, a native of India.

Here is a little path leading to the Curator's office, Garden laboratory, Agricultural pupils' class room, the nursery sheds, potting and packing houses, etc. A visitors book is kept at the office, and visitors should apply to the Curator for any information about economic plants. The nurseries are not open to the public, but may be seen by permission of the officer-in-charge. In them many thousands of seedlings of cacao, coffee, nutmegs, mangoes, etc. are raised annually, and distributed to planters at cost prices. Large nurseries for the raising of plants of limes, oranges, grape-fruits, and other plants which do not require shade in their early stages of growth, cover an area of several acres, and are situated near to the Roseau River, about a quarter of a mile from the office, and at Morne Bruce, a plateau on the hill immediately behind the Gardens. Full information on the subject is given at page 51 .

The work which is carried on in the nurseries is not conspicuous to the visitor, although it occupies the greater portion of the time of the skilled labour of the Garden. Nevertheless, it is most valuable work, which has produced in the past and will produce in the future, marked improvements in the quality of the crops of Dominica.

Several noteworthy plants are to be found in the short space between the office and the point at which the road branches. On the left is a fine tree of Cinnamomum Camphora, a native of China and Japan, now cultivated on a large scale in Formosa, from the wood of which the well-known camphor of commerce is obtained by distilling. It should here be mentioned that this particular tree is one of the oilbearing type, although of the same species as that which yields the solid camphor of commerce. This important difference existing within the tree affords no outward indication to enable an observer to distinguish one from the other. The only means of discovering the true camphor 
yielding tree is to make a distillation of leaves and twigs. In order to cbtain reliable stock for planting, the true camphor bearing tree must be selected from, for propagating purposes.

Note also Pachira aquatica; and a specimen of the wellknown Star Apple, Chrysophyllum Cainito, a tree with leaves of a golden hue beneath, the fruit of which is esteemed in the West Indies.

The border on the right, mainly composed of ornamental shrubs, contains a tree of Streblus asper, the chopped wood of which mixed with tobacco and rolled in Cordia leaf, forms the cigarette of Burmah. There is also in this border a specimen of Randia maculata-a striking object of beauty when in flower. The way now divides into four paths. The path straight in front runs through the experiment plots of cacao, citrus and nutmegs. At the corner of the cacao plot on the right-hand side growing over a large bush of the Japanese Cinnamon, Cinnamomum brevifolium, is the black pepper plant, Piper nigrum. The dried unripe fruits of this plant form the black pepper of commerce. They are picked as soon as the lower berries of the spike turn from green to red, and are then dried in the sun. To obtain white pepper the outer covering must be removed before drying, the berries being allowed to turn red before picking, when the outer fleshy part becomes pulpy, and can be easily removed. Turn now to the right, and take the path which runs parallel to the nursery sheds.

Following this path several interesting plants of economic value will be found. On the right-hand side, growing over the fence, observe three handsome climbers: Congea tomentosa with its sprays of minute white flowers and large bracts of a delicate carmine colour ; Combretım laxum, a free flowering plant bearing masses of bright scarlet flowers; and Strophanthus Preusii with attractive flowers of peculiar structure. A small tree of Strophanthus Jackianus, will be found close by. In front of the fence is a large clump of Alpinia Galanga, one of the ginger tribe ; and the well-known Granadilla, Passiflora quadrangularis of the West Indies. The tall plant here is Pleomele ugandensis, and differs somewhat in its habit of growth from its relation, Pleomele fragrans, standing a little further away. Between these two specimens 
is "Bon Reha," Villebrunea integrifolia, a small tree native of India and Malaya, from which ropes, mats, etc. are made. Note here a specimen of the Anchovy Pear, Grias cauliflora, native of the West Indies. Growing over the nursery sheds are the South American Odontadenia speciosa, a handsome climber which makes a splendid show when in flower; and the Garlic Shrub, Bignonia alliacea, so named because the leaves when bruised emit a powerful odour resembling that of garlic. The latter is used in some parts of the West Indies as a substitute for the true garlic, Allium satioum. Here also are the Japanese Cinnamon, Cinnamomum brevifolium; Saraca cauliflora, a flowering tree; Clibadium Vargesii, a native shrub, the leaves of which, when bruised, are used for stupifying fish in rivers; and the Papaw, Carica Papaya, which yields a fruit highly esteemed in the tropics: the juice of the unripe fruits yields Papain, now much in request in medicine as a digestive. In front of the last named plant is a tree of Brownea sp. which bears flowers nearly three times the size of $B$. coccinea, noted elsewhere. Further on is the Bael fruit, Aegle Marmelos, a reputed remedy for dysentery and diarrhoea; and the true ginger, Zingiber officinale, the clean and dried rhizomes of which form the ginger of commerce. Plants of the wild ginger, known as the Ginger Lily, Hedychium coronarium, will be found close by after turning the corner to the right. At one time this plant was under consideration as a source of material for paper-making. Note also the Coca plant, Erythroxylon Coca, from which is obtained the drug cocaine. At the corner is the Sapodilla, Achras sapota, a well-known fruit tree of the West Indies. The undergrowth in this corner consists of species of Sansevieria.

Along the short path on the right are arranged severa: other tropical fruit trees. Proceeding up to the path, note on the right-hand side the Mammee Apple, Mammea americana, the flesh of which, when made into a preserve, strongly resembles Apricot jam; the Loquat, Eriobotrya japonica; the Bread fruit, Artocarpus incisa, a native of the South Sea Islands, whose large green compound fruit is eaten as a vegetable, either roasted or boiled. Close to the lreadfruit are its congeners, Artocarpus Lakoochn, producing an irregularly shaped orange-red fruit, the pulp of which is acid 
and of a peculiar flavour; and the Jack Fruit, Artocarpu integrifolia, a tree cultivated in Southern India for the sake of its large fruit and numerous seeds. The timber of the Jack is largely used in India for making furniture. Note also the Guava Berry, Eugenia lineata, native of the Virgin Islands, whose small fruits are used in the preparation of liqueur : and the well-known Golden Apple, Spondias borbonica. Interplanted with the above are plants of the Manila Hemp, Musa textilis, distinguished from the common plantain or banana by its rather narrower leaves and its hard, woody, and non edible fruit. It yields the best of all the white coralage fibres. For its successful cultivation it requires a rich soil, and an abundant $\mathrm{r}$ infall well distribate 1 thro ghout the year.

Bordering the opposite side of the path is a tree of Lignum Vitae, Guaiacum officinale, which yields a resin used in medicine and produces an extremely hard and tough wood, much used for pulleys, pestles and mortars. Next is the Governor plum, Flacourtia Ramontchi, and further in the Bilimbi, Averrhoa Bilimbi, and its ally, the Carambola, Averrhoa Carambola. Both of these species vield acid fruits used for making jams, and for pickling. Here also will be found nine plants of the Chicle Gum tree of British Honduras Achras spp. and Rheedia edulis, the fruits of which have a pleasant acid taste. Note also "Mountain Pride" Spathelia simplex, of Jamaica; the Horse Radish tree, Moringa pterygosperma, the roots of which are used as a substitute for horse radish, the seeds yielding a valuable oil known as "Oil of Ben" ; and Erythrina senegalensis, a handsome flowering tree, related to the Nortels which are much used in the West Indies as shade trees for cacao and other crops.

The hedge on the cemetery boundary is made up of Congea tomentosa, and "Corallita," Antigonon leptopus. In front of this hedge is a row of Papaws. On returning along the path there may be seen the Indian Mulberry, Morinda citrifolia, whose roots yield a red dye; the Balata tree, Mimusops globosa, of British Guiana; and a showy Indian tree, Cochlospermum Gossypium, the source of Kuteera gum.

At this point we enter the lower Garden path. To the right the way leads to the upper slopes of the Garden $b_{y}$ a zig-zag path which rises to an elevation of about 120 feet, 
then continues for a considerable distance on the level and descends to connect with the lower Garden path near to the Emsall Gate. The distance from the present position to where it again connects with the lower path is half a mile. By following the hill path, good views of the Gardens can be obtained, but a greater number of interesting plants will be seen by following the lower walk, which also leads to the Emsall Gate, and is a shorter route.

Before proceeding along the lower path, a number of interesting trees may be seen by turning to the right in the direction of the hill path for the short distance that it continues on the level. On the right are Posoqueria latifolia, a small tree bearing white, sweet-scented flowers; the Champac, Michelia Champaca, an Indian tree, venerated by the Hindoos, which bears fragrant orange-coloured flowers; Ficus Parcelli with its large leaves curiously mottled with white; and the red silk cotton tree, Bombax malabaricum, a striking object when in flower. Further in is Eugenia caryophyllata, whose dried unopened flower-buds form the cloves of commerce. Their usefulness as a spice and in medicine is well known.

On the left is a fine tree of Bois d'Inde, Pimenta acris, a native tree, from the leaves of which is distilled bay oil, largely used in the manufacture of bay rum; also a fine specimen of Eucalyptus tereticornis, the Red Gum tree of Australia. Some 150 species of Eucalyptus are known, manv being of great value. The one growing so well here is utilized in Australia for wheelwrights' work. Other kinds will be met with later. The large Camphor tree on the right is another of the oil bearing type. Three young plants of the same species jielding the camphor of commerce will be roted on the opposite side of the walk. Extending up the slope, ehind the Eucalyptus tree, are several Flamboyant trees Poinciana regia. Across the cultivated hollow will be seen a collection of rubber yielding trees, consisting of the Para rubber, Hevea brasiliensis, now so largely planted in the East; the Mexican rubber, Castilloa clastica; and the Lagos rubber, Funtumia clastica; also specimens of F. africana and i. latifolia, both of which yield inferior rubbers. 
Returning to the signpost, the lower Garden path should now be followed. During its entire distance it follows the windings of the base of the Morne. It passes through a good deal of cacao cultivation, but no reference is made in this section of these notes to the various economic cultivations in the Garden. Only the interesting plants which border either side of the route will be noticed. For information respecting the various cultivations, the visitor is referred to page 45 where explanatory notes are given on the various economic plants under cultivation.

Observe on the corner near the signpost a large specimen of Yucca aloifolia, a very handsome plant when in flower also various Bromeliads growing at the base of this plant, including: Aechmea fulgens; Bromelia pinguin; and Pitcairnia coccinea.

On proceeding along the lower Garden path for a short distance, it may be observed that the slopes of the hill are planted with Guinea grass, Panicum maximum, probably the best fodder grass of the tropics. On the lower slopes, intermixed with the Guinea grass, are three members of the Anonaceae, namely, Custard-apple, Anona reticulata, Sugarapple, A. squamosa and Sour-sop, A. muricata; also the Surinam Cherry, Eugenia Micheli; Hog-plum, Spondıas lutea; and a small collection of various Guavas, Psidium sp.

Planted on the upper slopes is the Roble tree of Trinidad, Platymiscium platystachyum, a handsome flowering tree. Also the following native trees:-

Pain D'Epices, Lucuma multiflora, one of the largest trees of the forest. The wood is used for mill work, rollers, etc. The yellow fruit, which is edible, possesses a spicy flavour hence its name. In former days the fruit was collected in the forest and brought to market for sale.

Bouis, Chrysophyllum glabrum, a large tree which yields a durable wood, and bears edible fruits of a dark purple colour. These are known locally by the name of Star plum.

Bois Diable, Licania hypolenca, the wood of which is very hard but does not last under moist conditions. It is much used for fire-wood and for making charcoal. 
Tendre Acailloux, Piptadenia peregrina, a small tree with rough bark; the wood is used for cabinet work.

Surprise is sometimes expressed by visiting botanists at the comparative fewness of native plants in the Botanic Gardens. A perusal of these pages, however, will show that a considerable number of local specimens are grown. That many others of great interest are not grown is largely due to unsuitable climatic conditions, and not to lack of interest in this very important matter. Dominica, though a small island, varies greatly in climate and rainfall. Trees growing under perpetually damp conditions with an annual rainfall of 200 inches and upwards, will fail in many cases to grow in a comparatively dry locality like the Botanic Gardens, where the average annual rainfall is 78 inches, and where there is a pronounced dry period each year of about three months duration. It is probably due to these conditions that such fine specimens as Bois Pain, Talauma Plumieri; a remarkably fine flowering tree, Bois Bambarra, Diospyros Ebenaster-an interesting species the pulp of whose fruits are used to kill fish-and a number of others have failed after repeated attempts to exist in the gardens.

To the left of the path is the Malay Apple, Eugenia malaccensis, a very handsome tree when in flower. The fruit, though edible, is not of much account.

Rounding the corner on the right-hand side near to the foot path are: Crescentia cucurbitina, a relation of the Calabash tree, Crescentia Cujete, and the "Bread and Cheese" tree, Pithecolobium unguis-cati, native of the West Indies. The latter is generally employed as a hedge, and rarely allowed to reach the dimensions of a small tree. Further along on this slope is a collection of mangoes including Peach, Malda, Julie, Fifine Gabrielle, Lorieau, Savanna and Cambodiana, all of which are grafted. Also Cambodiana and Java seedlings. Next to the mangoes are two rows of young plants of Quebracho Colorado, Quebrachia Lorentzii, a large forest tree of Argentina, the wood of which is hard and durable and yields a valuable extract for tanning. The bark is used in medicine. 
Several trees of great interest are growing in the small ravine close by. These include the Souari or Butter-nut of British Guiana, Caryocar muciferum, which yields a nut possessing a fine flavour; Tonka Bean, Dipteryx odorata, whose fragrant pods are used in perfumery ; and the Breadnut of Dominica, Artocarpus incisa, var. seminifera; the latter not to be confused with the Bread-nut tree of Jamaica and West Africa, which will be referred to later. Also trees of the Avocado pear, Persea gratissima, a fruit much esteemed in the West Indies, and now largely grown in the Southern States of America. A clump of native Balisier, Heliconia Bihai, is growing at the end of the ravine. At this point specimens of the Bois Flot or Corkwood, Ochroma Lagopus, may be seen growing on the slopes about the upper garden path. This tree yields a wood of remarkable lightness.

Resuming the main path, a group of Divi-Divi, Caesalpinia coriaria, growing on the bank to the right, should be noticed. The small pods contain a considerable percentage of tannin, and were formerly an article of export. Near by is the West Indian Calabash tree, Crescentia Cujete, the fruit of which is used for a variety of purposes, the hard woody shell being made to serve as basins, cups, water-bottles, etc. ; the pulp is used as a medicine, acting as a purgative and considered to be beneficial in diseases of the chest. There is also grouped here several Nicaraguan shade trees, Glivicidia maculata, one of the best of shade trees for cacao cultivation. In Nicaragua, where the tree is a native it is preferred to all other shade-giving trees for this purpose. In Dominica the tree is planted as a nurse plant for young lime trees, and for mulching purposes. When in flower this tree is a striking object of great beauty.

Taking the left-hand side of the path commencing near the entrance to the ravine, note the Marmalade plum, Lucuma mammosa, a native of the West Indies and Tropical America, where it is cultivated for the sake of its fruit which is used for making a kind of marmalade; Akee, Blighia sapida, native of Guinea, but now common in the West Indies and South America, where its bright red-coloured fruits are occasionally eaten; Anona Buchanani, a species closely allied to the Sour-sop, Anona muricata; and the famous Mangosteen tree of the East,. 
Garcinia mangostana. This specimen first fruited in 1908, sixteen years after it was received from the Royal Botanic Gardens, Kew. The Mangosteen is one of the most delicious fruits of the tropics.

On the opposite side observe a large tree of Sterculia carthaginensis, a native of America, from Mexico to Brazil. The seeds which are about the size of pigeon's eggs, are, like those of many other species, commonly eaten as nuts by the inhabitants of that region. A little further along growing quite close to the path is Euphorbia splendens, a showy dwarf plant of Madagascar.

On passing the end of the straight path on the left, which leads to the Curator's office through the experiment plots, observe the Shea Butter tree, Butyrospermum Parkii, whose seeds yield a fat which is used as butter by the natives of West Africa. Shea butter is used to a certain extent in the manufacture of margarine, and for other purposes. Next is the Madagascar Voa-Vanga, Vangueria edulis, an edible fruit ; and further on a tree of the Durian, Durio zibethimus, a fruit remarkable on account of its fine flavour and powerful odour. It is largely cultivated by the natives of the Malay Archipelago for the sake of its fruit, which during the season, forms the greater part of their food. Behind the Durian are several plants of Cinnamomum zeylanicum, the bark of which forms the cinnamon of commerce. Further in may be seen examples of the Tea plant, Camellia Thea var. viridis; and the Kaki or Date plum, Diospyros Kaki, a Japanese fruit tree. Continuing, note Myroxylon toluifera, the source of Balsam of Tolu, used in medicine as an expectorant and stimulant; the fine flowering trees, Cordia Sebestena and Monodora tenuifolia; at the foot of the latter is the shrubby Ardisia Oliveri, remarkable for the beauty of its flowers. Further in are two interesting specimens of Theobroma$T$. bicolor, the Tiger Cacao, and $T$. pentagona, the Alligator Cacao; both are natives of Nicaragua: the latter species yields cacao beans of considerable value. On the right are several plants of Malabar Cardamoms, Elettaria Cardamomum. 
At this point the path divides. The main route continues by the path along the base of the hill in order to make the circuit of the Gardens, but it is now intended to note the interesting plants along the lower path until it joins the Mahogany Avenue, afterwards returning to the present position to resume the main route.

Following the lower path note on the right the Topee Tambou of Dominica, Calathea allowvia, whose tubers possess a pleasant nutty flavour, and are used as food. Next will be found Baikiaea Eminii, a handsome flowering tree from Uganda-closely resembling $B$. insignis, already noted; Cola Afzeli, a tree allied to the species yielding the Cola nuts of commerce; the slender-stemmed Cedron, Simaba Cedron, the seed of which is held in high repute by the natives of Tropical America as a remedy for snake bite ; and the Garlic Pear, Crataera gynandra, the bark of whose roots is used as a blister. Near by is the Cayenne Guava.

Growing in front of the Tangerines on the left-hand side near the edge of the walk will be found : Jaboticaba, Myrciaria cauliflora, a favourite fruit teee of the Brazilians; Lansium domesticum, a moderate-sized tree producing clusters of edible berries much relished in Malaya where the tree is a native; Nephelium Longamum, a native of Southern China, and much cultivated in that region for the sake of its fruits which closely resemble those of the Litchi, Nephelium Litchi, an allied species; and Poutaria suavis, native of Uruguay, which bears a pear-shaped fruit having an extremely agreeable taste, and possessing a finer scent than a ripe pine-apple. These fruit trees are under experimental cultivation, and it is hoped tot establish them in this island-particularly the first and last named kinds.

Continuing, note a good specimen of the Loquat, Eviobotrya japonica, and a fine tree of the Moreton Bay Chestnut, Castanospermum australe, native of Queensland, whose seeds when roasted resemble the common chestnut in flavour.

The Date Palm, Phoenix dactylifera, of which several specimens are here growing, succeeds fairly well under the climatic conditions of these Gardens, and large bunches of fruit of medium quality are produced annually. At the time 
the dates approach maturity, the weather is usually very wet, which necessitates the cutting of the clusters of fruit and their removal indoors in order that the ripening process may be completed under dry conditions.

Opposite the date palms is a plot of cacao which crop it is intended shall eventually be removed in order that this piece of ground may be devoted entirely to important exotic trees of economic or ornamental value. Some of these already interplanted here with the cacao include: Jaboticaba Myrciaria cauliflora; Poutaria suavis-two fruit trees noted already elsewhere along this path the Rambutan, Nephelium lappaceum, a large handsome spreading tree of Malaya, bearing a profusion of orange-yellow fruits, the pulpy parts of which have a pleasant acidulous taste; and the Queensland Nut, Macadamia ternifolia, a moderate-sized tree bearing nuts of agreeable.flavour; also Croton Tiglium a small Euphorbiaceous tree, native of India, from the seed of which Croton oil, a powerful purgative, is obtained; Taraktogenos Kurzii, a forest tree of Burma, Assam, etc., the source of Chaulmoogra oil used medicinally as a cure for leprosy and other cutaneous complaints; the East Australian Flame tree, Brachychiton acerifolium, an evergreen shade tree with magnificent trusses of crimson flowers; and Cassia Sieberiana a handsome flowering tree of Northern Nigeria. There are also growing here the Otaheite Gooseberry, Cicca disticha and young plants of the Mahwa tree of India, Bassia latifolia, whose fleshy sweet-tasting flowers are used as an article of food, and also yield by distillation an ardent spirit. The fruits are eaten raw or cooked, and from the seeds an oil is obtained which is used for cooking, as well as for soap-making.

Proceeding along the row of date palms to the point where the four paths meet, a number of interesting plants can be seen. Here is the Litchi, Nephelinm Litchi, a fruit tree of Southern China ; immediately opposite, a fine specimen of the Durian, a tree which has been already noted in these pages.

Bordering the path leading up to the stone steps, on the right hand side, note; Garcinia oblongifolia; Pernambuco Jaborandi, Pilocarpus pennatifolius, which yiclds an alkaloid, "pilocarpine," of value in medicine; Pilocarpus racemosus, native of Montserrat; and Pilocarpus sp. from Brazil, 
thought to be P. microphyllus, the "Jaborandy " or " Arruda Brava." Here also will be found specimens of the Monkey Cacao, Theobroma angustifolia, of Nicaragua; the Mandarin, Citrus nobilis var. major; the Sweet Lime, Citrus medica var. Limetta; Portugal orange, Citrus Aurantium, var. lusitanica, and the common orange, Citrus Aurantiumboth the sweet and sour varieties. There is also here a variegated form of orange, Citrus Aurantium var. variegata, a very ornamental tree.

On returning to the main path note at the corner on the right-hand side a tree of Teminalia scricea; and close by a specimen of the Malay apple, Eugenia cauliflora, in front of which is a hedge of the IVest Indian Cherry, Malpighia glabra. Opposite is the Bunya-Bunya Pine, Arancaria Bidwillii. Next to this fine specimen is a small collection of Garcinias, namely G. Morella, the source of Ceylon Gamboge, a gum resin used in medicine and the arts; $G$. indica, whose seed yields Kokum butter used in India in the preparation of ointments; G. Buchanani, and G. Xanthochymus, which yield an inferior Gamboge. Also notice a plant of the sugarcane, Saccharum officinarum.

On the right hand observe the IVood Apple, Feronia elephantum, an Indian tree; a fine specimen of Balsam of Copaiba, Copaifera officinalis; Oroxylon indicum, the bark of which yields a bitter tonic; and Sophora tomentosa. Behind these trees note Camoensia maxima, a handsome climber of Tropical Africa with large white and yellow flowers which are sweet-scented; Syncarpia laurifolia, a gum tree of East Africa ; Canarium commune, a native of the Moluccas, which yields the resin Elemi.

The picket fencing on the left is utilized for the support of a number of fine flowering creepers. Representatives of the genera Bignonia, Anemopaegma, Antigonon, Porana, Ipomoea, Camoensia, and Faradaya may be seen here.

Immediately behind the fencing is a row of coco-nut palms, Cocos nucifera, probably the most useful tree of the tropics. In the East every part-stem, leaves, flowering spathe, and fruit is of value. Many of the domestic uses to which the products of the coco-nut palm is put in the East are unknown in the Western Tropics. In the West Indian 
islands the palm is chiefly grown for the sake of its fruit from which is obtained the two most valuable products in a commercial sense, these being the dried kernel or copra, from which oil is expressed, (now an important source of vegetable butter), and the fibre obtained from the husk, known as coir, and much used for matting, brush-making and ropes.

The road now comes to the south end of the Mahogany Avenue, a point which the visitor will pass later, on making the complete round of the Gardens.

On returning to the main path observe at the corner on the left-hand side a specimen of the Bread-nut tree, Brosimum Alicastrum, native of Jamaica, where the plentiful supply of nuts produced by the trees in that island form a valuable food for horses and cattle, as also do the leaves. This tree also yields a valuable timber. Further on are specimens of Feijoa Sellowiana, a Brazilian fruit tree closely allied to the guava; Wormia Burbidgei, a fine flowering tree from North Borneo; the Wampi tree of China, Clausena Wampi; and Fagraea zeylanica, a flowering shrub of Ceylon.

Behind the two last named trees note Casimiroa edulis, and Diospyros Ebenaster, both natives of Mexico, where their fruits are highly esteemed. On the corner is the Gum Kino tree of India, Pterocarpus .Marsupium, and climbing over it is the Kaffir orange, Strychnos spinosa. It is now proposed to return to the foot of the walk near the Bread-nut tree and note the plants on the right-hand side, leading up to our present position.

The agaves on the corner are the spiny and spineless varieties of the valuable fibre plant, Agave sisalana: the spiny kind is cultivated in Iucatan; the spineless variety in the Bahamas. Immediately behind these plants are specimens of Brexia madagascariensis and of Parkinsonia aculeata.

The strong growing creeper on the pollarded tree is Anamirta cocculus, the source of Cocculus Indicus, used chiefly in the preparation of ointments in medicine, and in the adulteration of beer. Continuing, note Thunbcrgia grandiflora, a creeper with blue flowers; Yucca gloriosa; and a plant of Clavija ornata. 
The huge massive climber ascending the trunk of the tall palm, Dictyosperma album, is Strophanthus gratus, a very showy plant when in flower. At the base of this climbing plant is a fine clump of a tall-growing species of Costus, with large, white flowers: the green shoots it will be observed, have a peculiar spiral habit of growth.

Note here the entrance to a gully in which a number of interesting plants thrive. These will now be referred to before proceeding along the main path. The large palm growing on the left-hand side of the entrance is Arenga saccharifera, the sugar-palm of the Malay Archipelago, valuable to the natives of that region on account of its many uses. The stalks of the flowers yield large quantities of sap from which, on slight fermentation, toddy or palm wine is obtained. On evaporation the sap yields a quality of excellent sugar. If the tree is cut down before flowering, the starch contained in the central part of the stem may be made into a wholesome meal somewhat like sago. A huge specimen of Bougamvillaea glabra wil' be observed climbing over a Catalpa tree on the right of the entrance. Some distance off are clumps of Carludovica palmata and C. jamaicensis, members of the Cyclanthaceae. The young leaves of this plant furnish the material for making Panama hats. Further along is a climbing Aroid, Monstera deliciosa, a Mexican plant which bears a fine flavoured succulent fruit. Higher up the gully are several specimens of the "Bastard Cabbage Bark" tree, Andira inermis, a native of the West Indies, used as an anthelmintic : and the Butter tree of West Africa, Pentadesma butyracea.

A small collection of palms, numbering about twenty genera, is grown in and about this corner ; the more important species are; Verschaffeltia splendida, Stevensonia grandifolia, Licuala grandis, Pinanga Kuhlii, Thrinax Morrisii, Ptychoraphis angusta, Martinezia caryotaefolia, Elaeis guineensis, Hyophorbe Verschaffeltii, Dictyosperma album, Acanthophoenix Alexandrae, Areca glandiformis, Washingtonia sonorae, and Euterpe edulis.

Continuing on the path at the base of the hill, note on the right Mangifera sylvatica, an Indian tree; the Jujube, Zizyphus Jujuba, which is widely cultivated in the East for 
thesake of its fruit; and another species of Zizyphus, the specific name of which is not known. Further along will be noticed the Jamaica Allspice, Pimenta officinalis, largely used as a spice and in medicine for its aromatic and stimulant properties; and two species of Manihot, namely: $M$. glaziovii,(Ceara Rubber), and M.dichotoma, (Jequie Manicoba), both of which yield rubber and are suitable for cultivation in dry climates. Behind the plants mentioned is a collection of the best varieties of grafted mangoes, Mangifera indica, an Indian tree now widely cultivated throughout the Tropics for the sake of its delicious fruit. The varieties growing here are :-Julie, D'or, Divine, Amelie, Gordon, Peters, Bhadoorea, Pairi, Haden, Mulgoba and Alphonse. Higher up the slope above the mangoes are plots of Para, Mexican and African rubbers; also specimens of Congo or Sierra Leone Rubber, Landolphia owariensis. Other plants growing on this slope, taking the specimens nearest the foot path are: Vitex divaricata, a native timber tree, over which is growing Strophanthus dichotomus; the well-known Brazil nut, Bertholetia excelsa ; a white flowered variety of "Savonette," Lonchocarpus violaceus, and Schimus terebinthifolius. Also Lysidice rhodostegia, a large showy tree native of Southern China ; the Java plum, Eugenia Jambolana; and the Cashew, Anacardium occidentale, remarkable for its kidney-shaped fruit, which is placed on the end of a fleshy stalk. The tree yields a gum, and the kernel of the fruit, after being roasted, is highly esteemed as a nut. It is essential that the kernel should be roasted before eating as the outer greyish covering contains a quantity of black, extremely acrid, caustic oil, which causes very severe burning of the lips and tongue, and is poisonous. The heating process destroys the poisonous and caustic properties, and renders the nut wholesome and agreeable.

On the upper part of the slope, behind the trees just mentioned, will be found: Albizzia moluccana, used as a shade tree for cacao in Ceylon; Peltophorum africanum, a fine object when in flower; Haematoxylon campechianum, a small spreading tree of Central America-now naturalized in Dominica-the heart wood of which is the well-known logwood of commerce and yields the best deep red and black 

dyes ; Albizzia Lebbek, discourteously called Woman's Tongue in many parts of the West Indies, owing to the continuous noise made by the rattling of its dry thin pods. The heart wood of this tree is very dark and heavy and is known in Barbados as Ebony.

On the left-hand side of the walk note: the Jamoon Eugenia paniculata; Psendospondias macrocarpa; Anacardium excelsum; and the Macassar oil tree, Schleichera trijuga, a large tree native of India and Ceylon. This tree yields a good quality timber, and is frequented by the lac-insect. Considerable quantities of Stick-lac, from which part of the shellac and lac-dye of commerce is prepared, are collected in India and Ceylon from its young branches. Note also Mimusops hexandra, a moderate sized tree of India and Ceylon, whose bark yields tannin; and Pois-doux, Inga laurina, a leguminous tree used in the West Indies as a shade tree and for planting in wind belts. Immediately opposite the stone work steps is the Carib Wood of Dominica, Sabinea carinalis a small tree used for posts. It is one of the finest flowering plants of the Island. On the left, note Filicium decipiens, a Ceylon tree with elegant fern-like leaves, which yields a strong wood valuable for building; and Terminalia edulis, a recently introduced tree, native to the Philippines.

From this point to where the main route connects with the hill path, the slopes on the right are planted with a collection of native and exotic trees. Among these note, bordering the path, the Dattock, Detarimm senegalense, a West African fruit tree; and Antidesma Bumias, whose bark affords a fibre from which ropes are made. The fruits are edible and the leaves are used as a remedy against snake bites and for other medicinal purposes. Further on note the Genip, Melicocca bijuga, whose small green fruits are well known; Cassia multijuga, a small tree bearing masses of yellow flowers, and a tree of a variety of Pimenta acris, known locally as Bois d'Inde citronelle. The oil obtained from this variety is of very inferior quality and is known to spoil the superior product when its leaves are by mistake collected and distilled with those yielding the genuine Bay oil. Also the Coco plum 
Chrysobalanus Icaco; and the Tamarind, Tamarindus indica, the pulp of whose pods, preserved in sugar, is exported from the West Indies.

Growing on the upper slopes are Sapium aucuparium, a rubber tree of British Guiana; the Bead tree, Adenanthera pavonina; Anacardium surinamensis; Trachylobium verricosum, the source qf Zanzibar copal, Enterolobium cyclocarpum, with handsome feathery foliage and curious circular twisted pods; and the Sandbox tree Hura crepitans, the seeds of which yield a purgative oil. When mature and dry the valves of the fruit separate with much violence. The seed cases are sometimes filled with lead and used as paper weights. Note also two specimens of the Silk Cotton or Kapok tree, Eriodendron anfractuosum. These two trees, though of the same species, are representatives of the two types producing fibre, the colour of which may be either white or brown according as to whether the type belongs to the Eastern or the Western Tropics. The colour of the fibre of the former is white, and is superior to that of the latter which is brown. The fibre is known as Kapok and is largely used for stuffing pillows, mattresses, etc.

The largest supply of the superior article comes from Java. In the West Indies the brown fibre is used locally for the purpose mentioned above.

The hill path which connects at this point leads to the upper garden path, and also to IIorne Bruce, a plateau 300 feet above the level of the Gardens, on which are situated the lime nurseries, various experiment plots, and the collection of Eucalypts.

Bordering the lower portion of the hill path are clumps of different kinds of bamboos, amongst which is the common bamboo, Bambusavulgaris; the Male Bamboo, Dendrocalamus strictus; the handsome Cephalostachyum pergracile, from the Himalayas; and Thyrsostachys siamensis. The innumerable uses to which the bamboo can be put have often been written about at considerable length. It may be sufficient to mention here that the common bamboo supplies the many thousands of pots used annually in the nurseries, and that in the dry season its leaves afford valuable fodder. The early stages in the growth of a new shoot are very interesting, and may be 


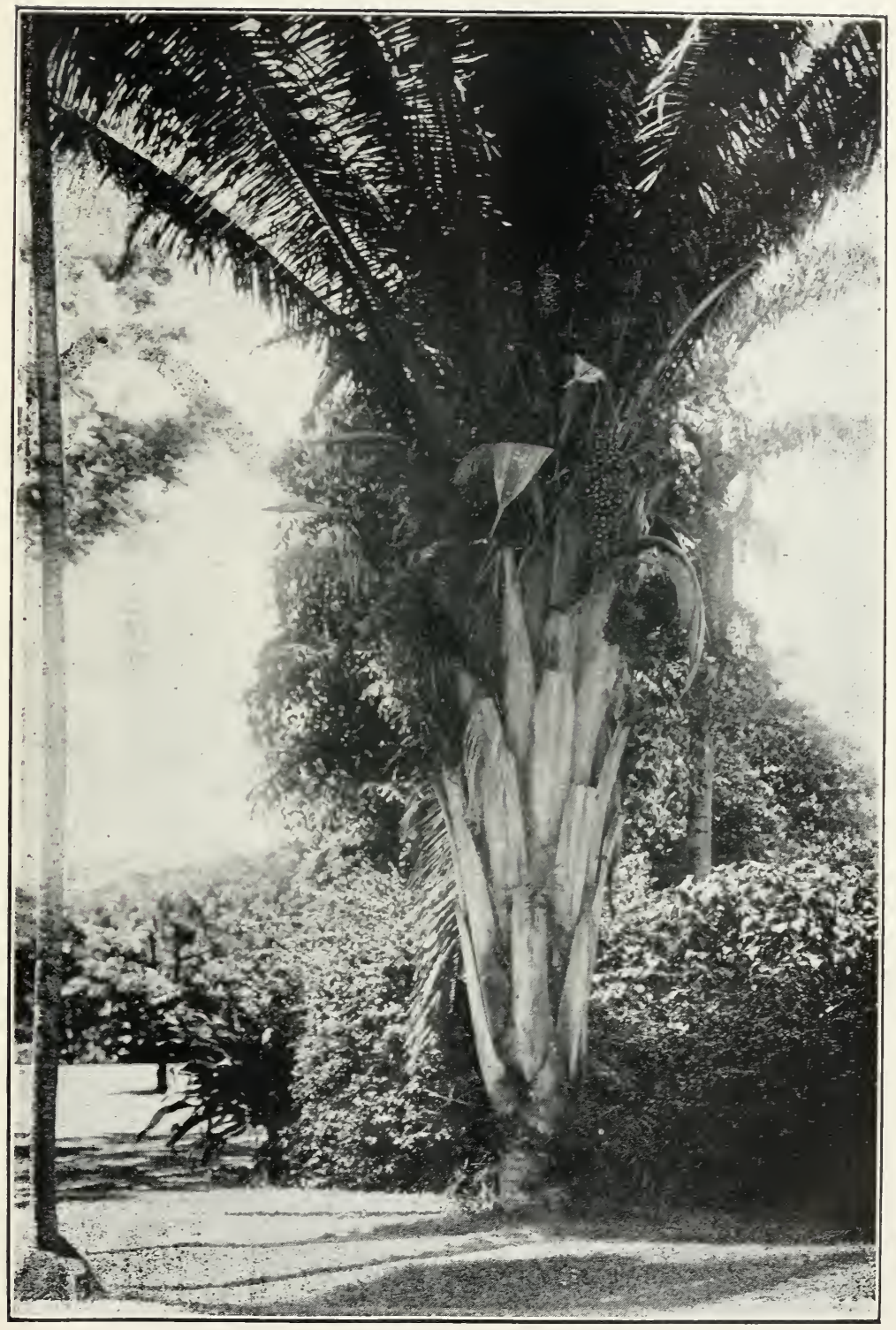

Cohcre Palm (Atlalea cohune), at the Eusall Gate. (See page 38.) 

seen during the wet season. Interplanted with the bamboos are several specimens of Spathodea campanulata which make a fine display during the flowering season.

Proceeding on the main route, note on the right specimens of Thevetia nerifolia, a plant with glossy foliage and yellow flowers, which yields the "lucky seeds" so much in request for wearing as charms in the West Indies. The milky juice of this plant is poisonous. On the left is Mimusops Schimperi, a native of Abyssinia, said to be the Persea of ancient writers; Khaya senegalensis, the source of African mahogany; and the Potato tree, Solanum macranthum, which bears large white and blue flowers. This plant is remarkable in being one of the few of the Potato family, to which order of plants it belongs, that take the form of a tree. Next are specimens of Amherstia nobilis, a very handsome flowering tree of Burma, and considered by some to be the finest of the flowering trees of the tropics. The flowers are of a salmon and yellow colour and are arranged on long pinkish coloured stems which hang down from the branches among the dark green foliage. The young shoots have a similar drooping habit, and during the growing period are an object of great beauty, the young leaves being of a brownish hue, and prettily marked with dark brown blotches.

Passing the north end of the Mahogany Avenue, made up of trees of Srietenia Mahagoni, and of Swietenia macrophylla, observe the two species, the former being the mahogany commonly grown in the West Indian Islands, and the latter the source of Honduras mahogany, and a rare plant in these islands at the present time. On the right is a small palmetum consisting of over thirty specimens. Conspicuous amongst them are the Cohune palm, Attalea cohune; Bentinckia nicobarica; Licuala elegans; various species of Sabal, Ptychoraphis, Cocos, Hyophorbe, and others. It is not necessary in a Guide Book to enumerate all the palms grown in the Gardens, but it may be stated that over 100 species representing fifty-two genera are grown, and that the collection is being increased each year. The large trees growing on the slopes behind the palms are Tectona grandis, the Teak tree of India and Burma, which yields a valuable timber of great durability; a local tree known as Resinier Grande Feuille, 
Coccoloba latifolia, one of the handsomest and most durable woods of this island; and Eucalyptus tesselaris, the Moreton Bay Ash, valued in Australia on account of its timber.

The path now joins the main carriage road at the Emsall Gate. The two palms flanking the entrance, though very much alike in general appearance, belong to distinct genera, the one on the right being Scheelea excelsa and the other on the left the Cohune Palm, Attalea cohme, of British Honduras. From the seeds of the latter an oil is expressed, which has a pleasant nutty flavour. Now that special machinery has been invented to deal with the hard shell of its fruit-a difficulty which had to be overcome before the oil could be extracted on a commercial scale-it is likely that the oil will find a ready use in the manufacture of margarine, for which purpose it is said to be very suitable.

Opposite the gate, and separated from the Garden by the public road, is a section-over 2 acres in extent-of the nursery grounds, which is utilized for raising budded citrus plants, Limes, Sugar cane, Coffee, Rubber, Onion seedlings, etc. If one stands near the Emsall Gate and looksalong the carriage road, the interesting plants on the left are Daniellia thurifera, the Bungo tree of Sierra Leone, which yields a fragrant resin; the Nabola fruit of India, Diospyros discolor; the Silky Oak of Australia, Grevillea robusta, a member of the Proteaceae, valued for its beautifully marked wood; and Gmelina arborea, a large timber tree of India, at the base of which is growing its ally the scandent Gmelina hystrix. Climbing over one of the mahogany trees is the Pelican flower, Avistolochia gigas, var. Sturtevantii, remarkable for its large, peculiarly formed flowers, whose structure enables them to entrap the unwary insects attracted by the foetid odour which they emit for this purpose. Further in is a specimen of Lagerstroemia parviflora.

Growing on the lawn on the right-hand side of the drive note, commencing at the gate: the Bull's Horn Acacia, Acacia sphaerocephala, native of Ilexico; the soap-berry tree of Dominica, Sapindus inaequalis; Triplaris surinamensis; Labramia Bogeri; the Indian Beech, Pongamia glabra; the silver foliaged Juniperus pachyphloea; Traveller's tree, Ravenala madagascariensis; Portlandia grandiflora, a West 


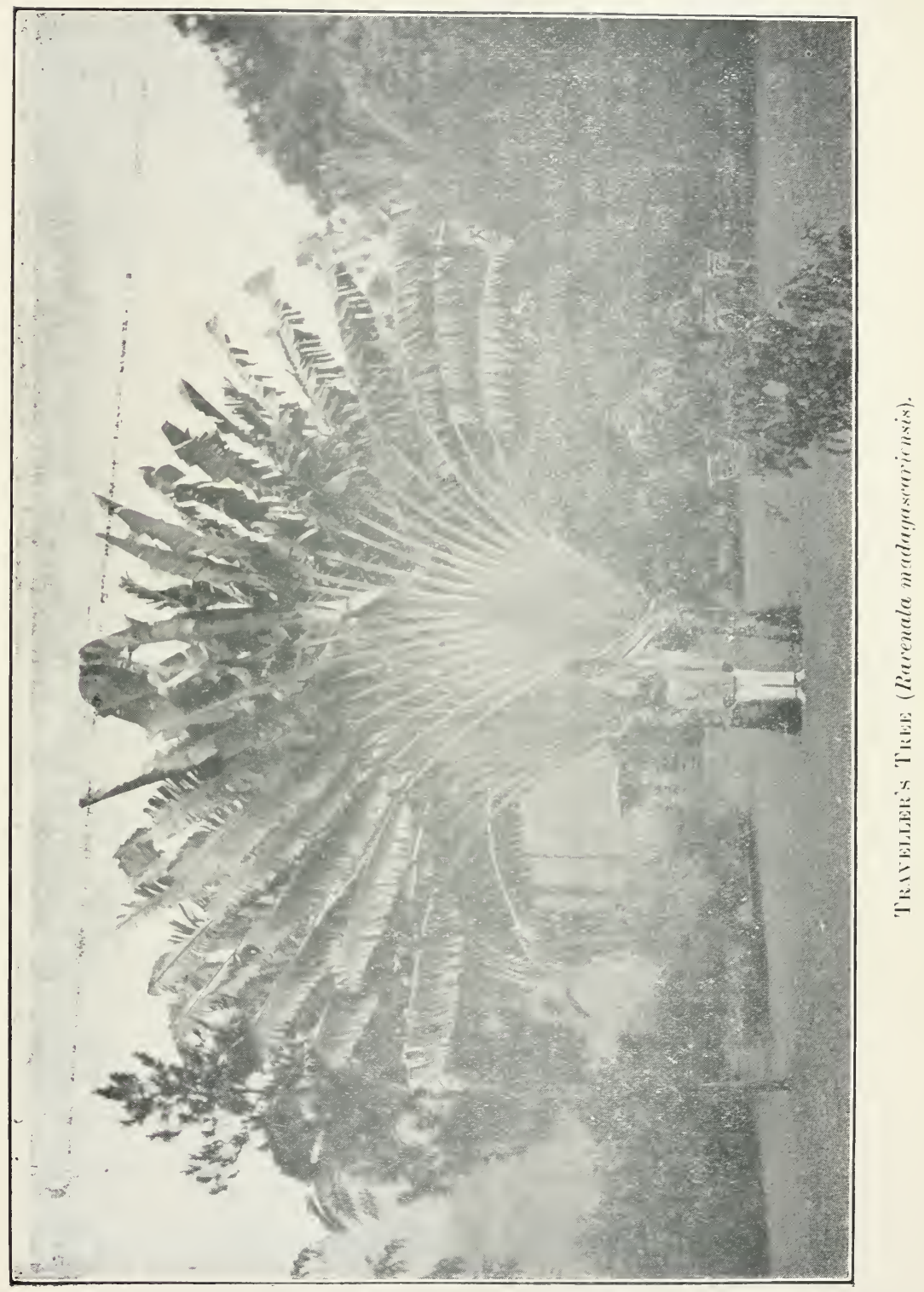



Indian flowering shrub; and Ixora odorata, a flowering shrub of Madagascar bearing sweet-scented white and pink flowers.

To the right lies the Main Lawn of over 2 acres in extent. Passing along the path in front of the border, observe the large spreading Saman trees, Pithecolobium Saman, a Venezuelan species, which are planted on three sides of the Main Lawn. This is one of the finest shade trees of the tropics. The sweet pods of this tree are largely eaten by horses and stock.

Growing upon some of the trunks of the Saman are climbing palms of the genera Calamus, and Desmoncus; a native monstera, a Philodendron with large perforated leaves ; Omphalea triandra; the "Hunterman's Nut," Omphalia megacarpa; and a small collection of native and exotic orchids.

The border facing the main lawn is closely planted with trees, palms, and shrubs. Conspicuous amongst the former are Jacaranda coerulea, a tree with fern-like foliage and blue flowers; the Santol tree, Sandoricum indicum, valued for the ornamental appearance of its orange-coloured fruits and the soft. white aril covering the seeds, which is edible; Givotia rottleriformis, the wood of which is exceedingly light, very soft, evenly grained, and much used in India for making toys ; and Heritiera macrophylla, whose leaves are of a silvery hue underneath, which gives rise to the name " Looking-glass tree" commonly applied to it. Other trees growing in this border are Rhynchosia Wallichia; Noronhia emarginata; Beilschmeidia Roxburghiana; Cassia nodosa; Albizzia lophxntha; and Uapaca Kirkii. Specimens of Murraya exotica, an: Steriphoma paradoxa, two handsome flowering trees, will be found also in this border.

Palms are here represented by Elaeis guineensis, the oil palm of West Africa, the fruits of which yield the palm oil of commerce, now used in enormous quantities in the manufacture of candles, in soap making, and for other purposes; and also the Carnauba or Wax palm of Brazil, Copernicia cerifera, a tree of great economic interest. The young leaves are coated with wax, which is detached by 
soaking them. It is then melted and formed into cakes, which are used in the manufacture of candles. The trunk yields a wood of great hardness, and the leaves are used for thatching, and for hat-making.

Amongst the shrubby plants are two species of Carissa: $C$. Carandas, and C. grandiflora, both of which bear white fragrant flowers, and edible fruits. The former is a native of India, and bears dark purple fruits; the fruits of the lattera South African species-are red. Both make good hedge plants.

Other shrubby plants growing in this border are: Thunbergia evecta; Leea sp. a handsome plant with orangecoloured berries; various Crotons, Cordylines. Calliandras, Ixoras, and other plants such as : Ravenala guyanensis; and Muehlenbeckia platyclada, the last named a curious bushy plant with flattened green stems, which serve as leaves, and bear numerous white flowers. This plant is a native of the Solomon Islands.

On reaching the corner at the end of this border will be found Ixora amboinica, and Ixora parviflora, both of which bear white, sweet-scented flowers; Oreinia cepiodora; Spiraea Reevsiana; and a species of Polyalthia; also, Martinezia corallina, a handsome dwarf palm native to Martinique; and Quebrachia Lorentzii, a tree already noted in this book.

On turning the corner and proceeding along the path, a row of mahogany trees interplanted with Casuarines will be noticed. There are specimens of Casumina cyulisetifolia, a leafless tree with jointed pendulous twigs, native to the Pacific Islands. It yields a wood of extreme hardness. On the lawn to the right observe several palms including three species of Corypha:C. elata, C. gebanga, and C. umbraculifera; and Arenga Wightii. Observe also Deguelia microphylla,an attractive tree with purplish flowers, used in Java on coffee plantations for the purpose of giving shade, and of supplying mulch: Hernandia sonora, the juice of the leaves of which is a powerful depilatory, destroying hair wherc $v e r$ applied, without pain ; and Celtis austrains, a native to Scuth Europe. North Africa and South Asia. This tree affords a hard and dense wood well suited for turner's and carver's work. The berries are edible. 

Rounding the corner by the pavilion observe two specimens of the Frangipani, Plumieria alba, bearing white flowers; also Bauhinia variegata, and Bauhinia purpurea, both of which are handsome flowering trees. Other trees near the corner are: the Jamaica Dogwood, Piscidea Erythrina, which affords a tough wood used for many purposes - the root bark being an intense narcotic; the Red Silk Cotton tree, Bombax malabaricum, mentioned elsewhere in this guide; and the Paradise nut of British Guiana, Lecythis Zabucajo. The seed of this tree, known also as Sapucaia nuts, are commonly sold in fruit shops, and are considered superior in flavour to, and more easily digested than the Brazil nut to which they are closely allied. Further along is a fine Indian bamboo, Melocanna bambusoides. The tree growing behind this specimen is Kydia calycina, valued for its mucilaginous bark, which is said to be used in the northern provinces of India to clarify sugar; a strong fibre is also prepared from the bark. Continuing along the path under the shade of the Saman tree note Peltophorum ferrugineum, a handsome quick-growing tree of Ceylon and Malaya. The flowers, which are sweet-scented and of a brownish-yellow colour, are borne in large erect panicles, and appear at irregular intervals, sometimes twice a year.

Pithecolobium Berterianum, a tall specimen growing behind the last named, affords a light shade, and is valued as an ornamental tree. Proceeding further observe on the lawn to the right, after passing the avenue of Acanthophoenix rubra, (already noted in these pages), a fine specimen of Myrospermum frutescens, a showy flowering tree of South America ; and further in, behind this tree, a bed of the Betel Nut palm, Areca Catechu, the seeds of which are commonly used throughout Ceylon, India and Malaya as a masticatory. In preparing the latter other ingredients are added, small portions of the mixture being taken and wrapped separately in leaves of the Betel Vine, Piper Betle, when it is then in a convenient form to use.

On reaching the corner take the path to the left. On the right will be found a bed of Randia Mussaenda, a shrubby plant bearing white flowers; and Acanthorhiza aculeata, a spiny paim of South America. 
At this point there is an avenue of palms, formed of Pritchardia pacifica, a palm of Fiji, alternated with Euterpe edulis, a native of Tropical America. Flanking the entrance on either side are clumps of a low-growing palm of Southern China, Rhapis flabelliformis.

Proceeding up the avenue the plants on the left are: Chrysalidocarpus lutescens; Cassia siamea, a fine flowering tree; Laportea longifolia; Pandanus Baptistii; and Excoecana Agallocha, a small tree native of India, with extremely acrid milky juice. Also a bed of Holmskioldia sanguinea, a shrub of Northern India, with orange-red flowers; a huge plant of the Talipot palm of Ceylon, Corypha umbraculifera; and immediately behind the last named a tree of Cananga odorata, which yields the perfume Ylang-ylang. Near the main drive note the Kei apple, Aberia caffra, native of the Cape and Natal. The fruits of this shrub are used in preserves when ripe, and the shrub itself, being armed with spines, forms a very useful hedge. A plant of Bougainvillaea spectabilis, var. laterita, with handsome brick-red bracts, is here growing over a Catalpa tree.

The plants of interest to be seen on the right-hand side of the avenue are Brinfelsia americana, a shrubby plant with pale yellow flowers; Shorea Talura, a timber tree of India; and specimens of Euphorbia and Hibiscus.

By crossing the carriage road an avenue formed of palms of Raphia vinifera is reached. This is the Wine palm of West Africa. It also yields a fibre used for brush making, which is known as Piassava Fibre or African Bass. The tree is put to many uses in its native country. An attractive feature about most of the palms in the Gardens is the natural ferneries that have become established on the trunks from spores carried by the wind and other agencies. This palm appears to offer the most suitable conditions for fern life, as, being of a low-growing inabit, it gives the requisite amount of shade and maintains the humidity of the surrounding atmosphere so essential to the well-being of this class of plants. Other Raphia palms growing in the vicinity are : $R$. pedunculata a very handsome species from Madagascar, situated on the right-hand side of the avenue near a large Talipot palm; $R$. taedigera, the Jupati palm of Brazil, used for many purposes 


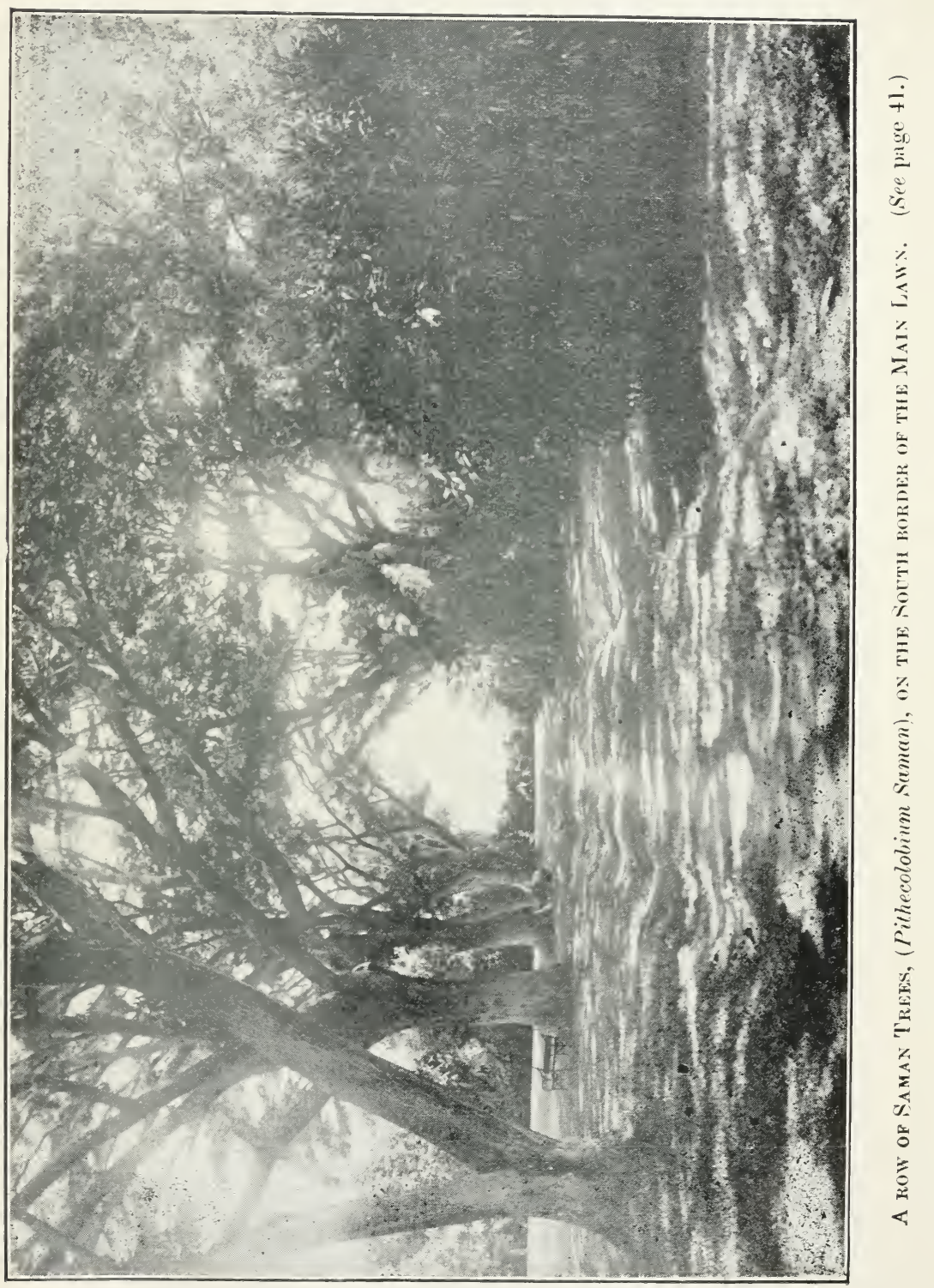



by the natives of that region. The latter will be met with later. Tabebuia pentaphylla, one of the finest flowering trees in the Garden, will be observed on the right at the entrance to this avenue. Further in, and bordering the carriage drive, is the native Coconier, Ormosia dasycarpa, a tree which yields a useful wood for all kinds of house construction work. Shingles made from this timber are said to be equal in durability to Wallaba. The seeds are hard, round, and of a bright scarlet colour with a jet black spot at one end. They are much in request for making necklaces.

A number of noteworthy plants are grown on the opposite lawn to the left of the avenue, amongst which is the velvet Tamarind of West Africa, Dialium guineense, whose small pods are covered with black velvet-like down. The pulp which surrounds the seeds has an agreeable acid taste. Next is Colvillea racemosa, a very showy flowering tree from Nadagascar; and further in are beds of Piychosperma Macarthurii, an Australian palm of bushy habit ; Excoecaria discolor, the under surface of whose leaves is of a dark red colour; and Kleinhorea hospita, a handsome Malayan tree bearing coral pink flowers. On the lower portion of the lawn are three specimens of the Coco-de-mer, or double Coco-nut, Lodoicea sechellarum, only native to the Seychelles. This rare palm is now being established in several West Indian Botanic Gardens. The rate of growth is slow, one leaf only being produced each year: The palm in its native habitat does not flower until about thirty years old; the fruits, which weigh from 40 to $50 \mathrm{lb}$., take ten years to ripen. The hard shell of the nut, which is often carved and ornamented, is highly prized. Prior to the discovery of the Seychelles in the year 1743 , the fruits had been picked up by mariners, and fabulous stories were told respecting their origin. Next is a small collection of African rubber-yielding plants, Landolphias, and plants of Strychnos, which may be seen climbing over the mahogany trees.

From this point onwards the path is bordered by a hedge of Burning Bush, Acalypha Wilkesiana. The tall palm growing just where the hedge commences is Raphia taedigera, previously mentioned. The Bauhinia growing close by is 
B. Galpini, a handsome South African species with bright red flowers. Behind the hedge the land is occupied by a large collection of grafted mangoes, Mangifera in icica, which includes such varieties as Alphonse, Daramia, Pairi, Kheershapottee, Bhadoorea, Langra, Julie, Divine, Bombay, Ceylon No. 1 and others.

Proceeding a short distance along the path a border will be met with on the left-hand side planted with various plants of ornamental and economic value, notably: the double pink Hibiscus; Rondeletia speciosa; Brownea Kervense; Pav tta caffra; small masses of the interesting China grass, Boshmeria nivea; and the Ramie or Rhea, Boehmeria tenaciss'ma. The latter are fibre plants, both yielding a fibre of great strength an fineness, but, up to the present, the difficulty of extracting it from the inner bark has not been satisfactorily overcome.

Other interesting plants in this border are the wild Lime of India, Atalantia monopyhlla, which furnishes a heavy closegrained wood suitable for cabinet work; Clerodendron Bakeri; and specimens of the Queen of Flowers, Lagerstroemia Flos-reginae, a large deciduous tree of India and Burma. The latter yields a valuable timber used in shipbuilding and all kinds of construction work. It is grown in the West Indies on account of the beauty of its regal purple flowers. Further along will be found the Sandal Wood, Santalum album, whose fragrant wood is much used in India for carving, for ornamental purposes, and for burning incense; and the well-known Pomegranate, Punica granatum. The dried rind of the fruit is of value as a remedy for dysentery, and, like the bark, is used for tanning; the root is an excellent vermifuge.

Immediately behind these trees is a collection of Mexican varieties of the Avocado pear, Persea gratissima var. drimyfolia.

The building on the right is a Cacao drying house, used for drying cacao. During sunny weather the sliding trays are drawn out into the open, but in dull or wet weather the trays are pushed under cover and drying is effected by means of flues heated from a furnace at one end, whilst at the opposite end a fan is kept going to keep the heat in circulation. Large quantities of cacao, as well as nutmegs and kola nuts, 


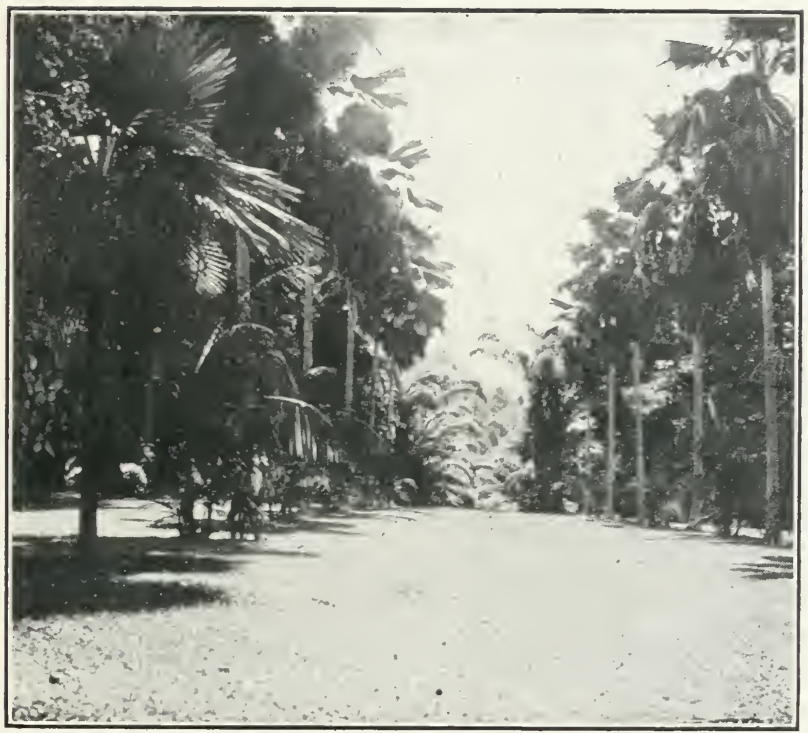

Lookmi sorth Alosi THE Arexte of PALys Pritchardire pacifica (ALTERxATED WITH Euterpe edulis). (See page 42.) 

pass through this house in the course of a year. Growing behind the cacao house is Tecoma serratifolia, a tree of great beauty during the flowering period, when it bears a wealth of bright yellow flowers.

On arriving at the end of the path note on the left Flacourtia sepiaria, a bushy shrub valued as a hedge plant on account of its spiny nature, and for its berries which have a pleasant sub-acid flavour when ripe.

The Curator's office is now reached and the walk around the Gardens is completed.

\section{Manurial Experiments with Cacao.}

The area under cacao cultivation in the Botanic Gardens is estimated at $7 \frac{1}{2}$ acres, of which over 4 acres, divided in ten plots, are devoted to manurial experiments. Five of the plots have been carried on for twenty years, and the others for fifteen years. The crop results have been carefully recorded over these periods, and tabulated for publication in the Annual Reports on the Agricultural Department. Very valuable information has been obtained from these experiments which has proved of great interest to planters engaged in cacao growing in this island and in other countries.

These plots have clearly demonstrated the prime need of the use of complete fertilizers in orchard cultivation, and the necessity of maintaining the humus content of the soil by the application of pen manures and mulches. By these means the fertility of the soil is kept up and the production of good crops over long periods is made possible.

The old series of experiments were brought to an end on June 30,1922 , and the new series, details of which are given below, were then commenced. In the new experiments, the ten plots fall naturally into four sections as regards soil and situation, therefore the plots within the various groups are comparable with each other. The first seven plots are on level land; the three others are situated on a hillside.

The new experiments, as proposed, should be of greater interest to planters than the old ones; but in this respect it should always be remembered that new series are the outcome of the work done, and the experience gained during the continuance of the first series of manurial plots. 
46

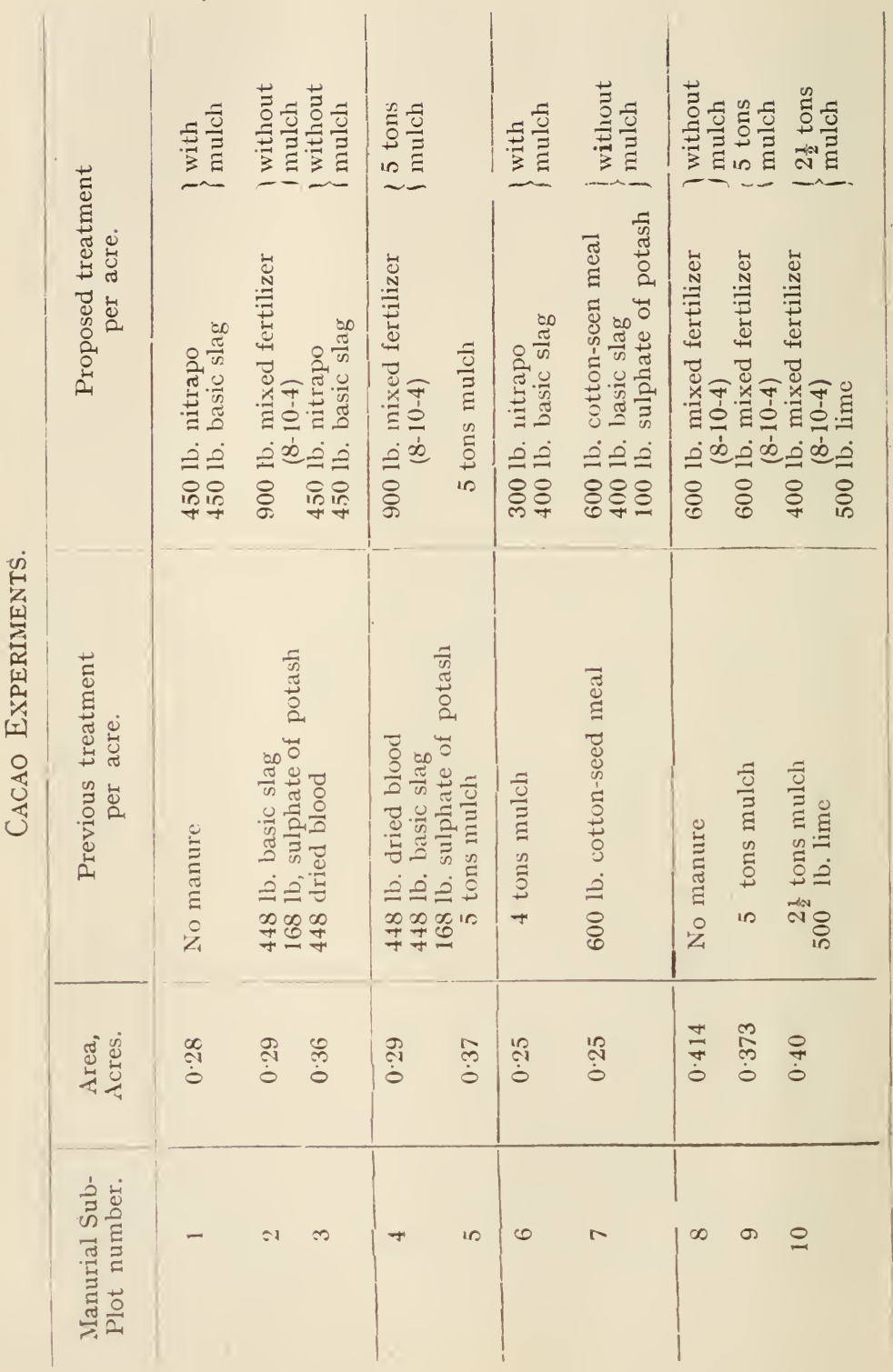




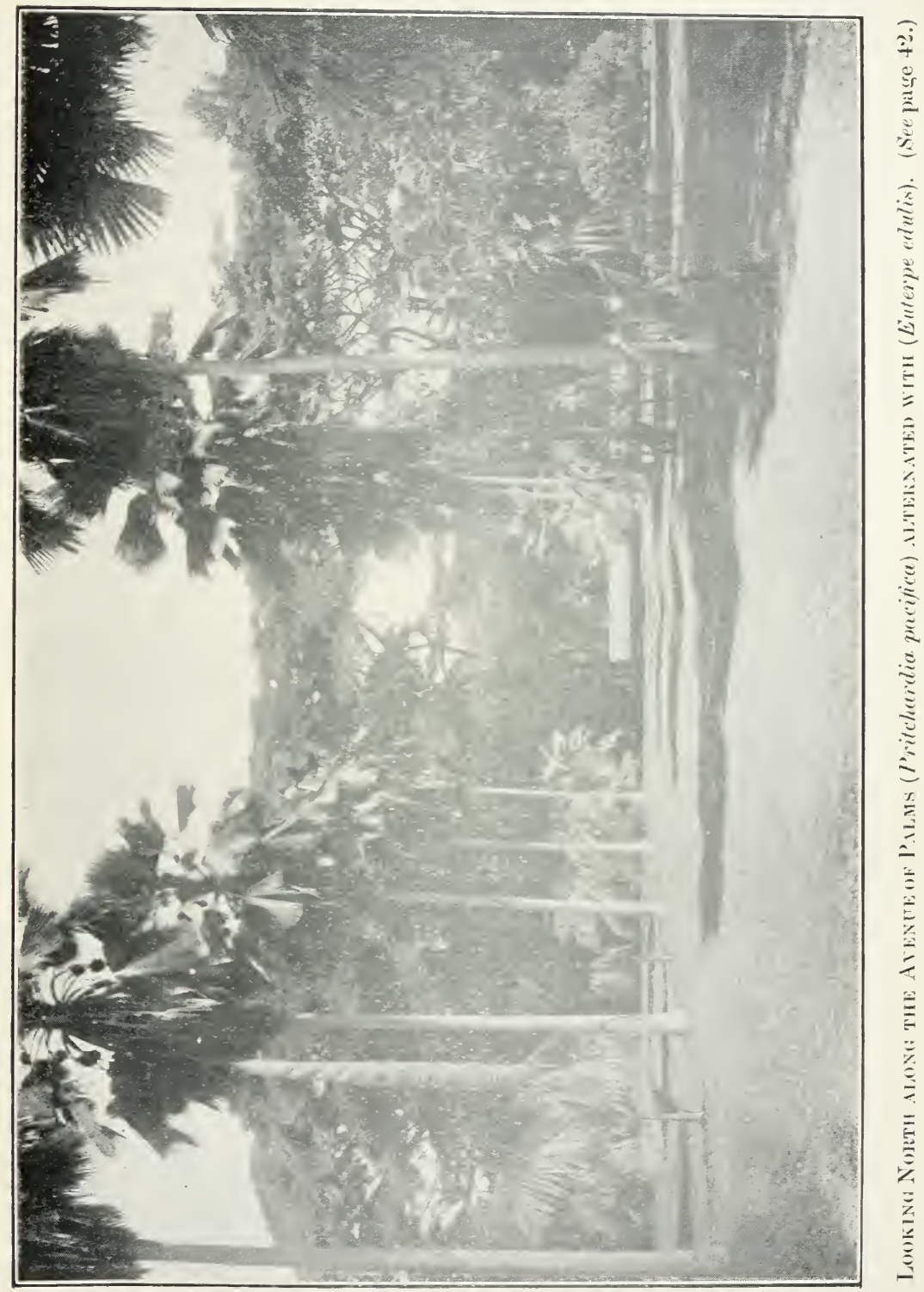





\section{EXPERIMENT Plots.}

Plot No. 1.-An area over $1 \frac{1}{2}$ acres in extent of established cacao trees (Theobroma Cacao), native of Central America, divided into five manurial plots. These have been maintained for twenty years (see Annual Reports on the Botanic Gardens), and they have afforded valuable indications in regard to the manurial treatment of cacao in the island.

The three varieties of Theobroma Cacao are known respectively, by the name of Criollo, Forastero, and Calabacillo, and there are sub-varieties existing between the main types. The Criollo variety yields the best produce, but it is delicate, and cannot be successfully grown on a large scale under the climatic conditions of Dominica. Consequently the hardy Forastero, and still more hardy Calabacillo, are chiefly grown.

The pods when ripe are cut off the trees, and placed in heaps. Women then break the pods and extract the beans, which are put in boxes to undergo fermentation for a period of six or seven days, care being taken to turn the beans daily. After this process is finished, the beans are spread out on trays, and danced upon or rubbed by hand, to remove the pulp, previous to their being dried for export.

Cacao is produced on a considerable scale in Dominica, the exports for 1919 having been 7,387 cwt., valued at $£ 37,293$.

Plot No. 2.-This contains fifty-two grafted plants of a selected variety of Forastero cacao. The plot is interesting as being one of the first field experiments with grafted cacao plants.

Plot No. 3.-This contains a small collection of citrus plants budded on sour orange stocks. Here may be seen the Shaddock and Pomelo, Citrus decumana, and the well-known Grapefruit-a variety of this species. Also the Portugal orange, Citrus Aurantium, var. lusitanica; the Sweet lime, Citrus medica, var. Limetta; and two kinds of the Lemon, Citrus medica, var. Limonum.

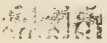

The various species of citrus now so widely cultivated in the Tropics are all of Eastern origin, and were originally introduced into the West Indies by the Spaniards. 
Plot No. 4.-On this plot are growing twenty-five trees of Cola acuminata, a tree of West Africa, one of the species which yield the Kola nuts of commerce. These nuts are said to be used in Tropical Africa in the same manner as betel nuts in Asia. They are chiefly valued in Africa for satisfying the craving of hunger, and for enabling those who eat them to endure prolonged labour without fatigue. There is a large internal trade in the nuts in that country.

Plot No. 5.-Here may be seen twenty trees of the Para rubber, (Hevea brasiliensis), native to the forests of the valley of the Amazon, and now extensively cultivated in the Middle East. This species yields the best rubber. The enormous demand which exists for rubber, and the many uses to which it is put are well known.

Plot No. 6.-This is devoted to Spineless lime plants, a variety of the common Spiny lime, (Citrus medica, var. acida). The common lime was introduced into the West Indies by the Spaniards. It is now extensively cultivated in Dominica. The fruit when ripe falls to the ground, and is then collected and placed in heaps for conveyance to the mill for crushing. The juice is exported raw for making cordials, and, when concentrated about $10: 1$, in order to reduce bulk, for making citric acid. This process of concentration unless carefully carried out is very wasteful, and, in order to overcome this preventable loss, the manufacture of calcium citrate, which represents a great advance over concentrated juice, was commenced in 1906. Recently a factory has been erected by the well-known firm of $\mathbf{L}$. Rose $d$ Co., Ltd. for the local production of the finished product, citric acid. Otto of limes is prepared from the rind of the fruit by the écuelling process, and essential oil of limes by distillation of the juice before it is concentrated or used in the manufacture of citrate of lime. There is also a considerable trade in shipping green limes to New York, Canada, and Great Britain, and a small business in pickling limes in salt-water for export to Boston, U.S.A. The value of the lime products exported from Dominica during 1919 amounted to $£ 196,401$.

Plots Nos. 7 and 8.-Both of these are manurial experiment plots of cacao (Theobroma Cacao). 

Plot No. 9.-The following varieties of the common Orange, (Citrus Aurantium), are growing in this plot: Washington Navel, Bahia Navel, Jaffa, Florida and Hybrid; also the Jamaica and Old Bahama varieties of the grapefruit (Citrus decumana, var.).

Plot No. 10.-Growing upon the hedges of Physic Nut, (Jatropha Curcas), are the Mexican vanilla (Vanilla planifolia), and the Vanillon, (Vanilla Pompona). The fragrant fruits of both species are well known, and largely used to flavour chocolates, creams, liqueurs, etc.

Here is also a small collection of the Indian oil grasses, namely, Ginger Grass (Cymbopogon Shoenanthus), Citronella grass, (Cymbopogon Nardus), Lemon grass, (Cymbopogon citratus), and Vetiver, (Vetiveria Zizanioides). The oils obtained from the leaves of the Cymbopogons, and from the roots of the Vetiver are largely used in perfumery, and for scenting soapś.

Plots Nos. 11 and 12.-These are devoted to the cultivation of the Nutmeg (Myristica fragrans), a native of the Moluccas. The fruit, a fleshy drupe, of a yellow colour, has the appearance of the European apricot. The fleshy exterior, which is used for making jam, splits open when ripe, disclosing the seed or nutmeg surrounded by the scarlet aril. The latter, known as mace when cured for market, is of a yellow colour. Nutmegs are largely used as a spice. An oil is obtained from the nuts by distillation, and nutmeg butter by pressure. Both substances are used for scenting soaps.

Plot No. 13.-On this plot are plants of hybrid cacao obtained by crossing Alligator cacao, (Theobroma pentagona), and Forastero cacao (Theobroma Cacao).

Here are also plants of Congo coffee, (Coffea robusta), a free growing prolific species from West Africa, which thrives with considerable vigour at low elevations. The white flowers of the coffee tree are produced in dense clusters in the axils of the leaves, and give the trees a fine appearance during the short time they remain open. They are succeeded by numerous fruits, each of which contains two seeds known as coffee beans. The fruits when ripe are picked from the tree, and passed through a pulping machine in order to remove the 
outer covering. The seeds are then washed, and undergo a cold fermentation for twenty-four hours in order to get rid of the mucilage which surrounds them. After drying, the parchment-like husk and silver skin enclosing the seeds are removed by machine processes. The coffee beans are then ready for market.

Growing on this plot are a few plants of the Kola nut, (Cola vera), from West Africa, a species which is said to produce finer nuts than those yielded by Cola acuminata.

Plot No. 14.- Selected varieties of West Indian Avocado Pears, (Persea gratissima), and the Mexican varieties Fuerte and Puebla, and others, are under experimental cultivation on this ground.

Plot No. 15.-Growing here are three species of cacao, namely, Forastero cacao, (Theobroma Cacao), Alligator cacao, (Theobroma pentagona), and Tiger cacao, (Theobroma bicolor). All the species named are natives of Central America: the two first named yield excellent cacao. The seeds of Tiger cacao are not of value commercially.

Plot No. 16. - On this area are trees of the well-known Tangerine orange, (Citms nobilis), and a few selected kinds of the Grapefruit, (Citrus decumana var.).

Plot No. 17.-This small plot consists of the Bush coffee, (Coffea stenophylla), Liberian Coffee, (Coffea liberica), and Abeokuta coffee, (Coffea liberica, var. Abeokuta). The berries of the first named are dark purple in colour when ripe. Both species, as well as the variety, are hardy and prolific, and though not producing the highest class of coffee, they are suitable. for cultivation at low elevations. Coffea arabica and its varieties, which produce the best coffee, thrive only at considerable elevations.

Plot No. 18.-A fairly large area under economic plants of great interest, interplanted with grafted Forastero cacao.

Plot No. 19.-A similar area, with the common seedling orange interplanted with seedling cacao. 


\section{Nurseries.}

The plants raised in the nurseries consist chiefly of limes, cacao, Para rubber, vanilla, coffee, nutmegs, the best varicties of grafted mangoes, and budded citrus, as well as timber and other useful trees.

The raising of plants for distribution at cheap rates forms a very important part of the work of the Gardens, and one which demands a good deal of the time of the staff.

The maintenance of Government nurseries is of very considerable assistance to planters, the latter being relieved of the work of raising and caring for seedling plants during their early stages. In the case of new settlers it enables the first cleared areas to be planted at much earlier periods than would otherwise be possible, thus effecting a gain in time which is often of the utmost importance to the planter.

The demand for plants continues on a large scale, and involves the upkeep of a nursery area of over 5 acres in extent.

It is doubtful if the nurseries can be extended further, and it is hoped that private enterprise will step in and continue the work started under Government auspices. In the present stage of agricultural development, a well organized nursery is a necessity to the planters of the Island.

Much work has been accomplished in the Government nurseries in applying the methods of budding and grafting to tropical economic plants not hitherto propagated by these means. It has been shown that the important cacao plant, which, until a few years ago, was exclusively propagated by seed, can now be increased by either grafting or budding, and these methods are now practised in the propagation of other fruits such as avocados, mangoes, and all kinds of citrus By these means it is possible to fix and increase any variety of these plants which observation has shown to be possessed of some special and desirable quality. 
In order to show the extent of the nursery work, a table of the yearly distribution of plants for fifteen years, 1905-6 to 1919-20 is given below :-

$\begin{array}{lllll}1905-6 & \ldots & \ldots & \ldots & 65,731 \\ 1906-7 & \ldots & \ldots & \ldots & 83,000 \\ 1907-8 & \ldots & \ldots & \ldots & 53,855 \\ 1908-9 & \ldots & \ldots & \ldots & 67,596 \\ 1909-10 & \ldots & \ldots & \ldots & 79,009 \\ 1910-11 & \ldots & \ldots & \ldots & 69,295 \\ 1911-12 & \ldots & \ldots & \ldots & 76,363 \\ 1912-13 & \ldots & \ldots & \ldots & 75,146 \\ 1913-14 & \ldots & \ldots & \ldots & 58,198 \\ 1914-15 & \ldots & \ldots & \ldots & 67,042 \\ 1915-16 & \ldots & \ldots & \ldots & 65,700 \\ 1916-17 & \ldots & \ldots & \ldots & 53,640 \\ 1917-18 & \ldots & \ldots & \ldots & 45,518 \\ 1918-19 & \ldots & \ldots & \ldots & 32,609 \\ 1919-20 & \ldots & \ldots & \ldots & 55,837\end{array}$

The average annual sale of plants during the above period is 63,000 . In addition there is also a considerable distribution annually of seeds of rubber, coffee, green dressings, fodder grasses, shade trees, papaws, vegetables, and of bud-wood of the best varieties of citrus.

\section{Morne Bruce Lands.}

The Morne Bruce lands may be reached by either taking the public road leading up the hill past the Cemetery, near the Roseau gate, or by following the path known as Jacks walk. This path takes a zig-zag course up the precipitous Morne Bruce cliff, and commences at the foot of the hill near the Emsall Gate.

By following Jacks walk, which is the most direct route, the visitor remains on Govermment land throughout the tour of the Agricultural Department, which extends beyond the Morne Bruce lands to the Valley where the Lime Experiment Station is situated. The Lime Experiment Station will be referred to later. 
In following this route the opportunity is afforded the visitor for inspecting at close range some of the native trees previously mentioned in these pages. In addition to the native trees and shrubs, several specimens of Bamboros will be observed.

The overhanging branches of the bamboos, and the various other trees and shrubs, afford a certain amount of shade, and make conditions for walking up the steep slope more pleasant than would be the case if the path were exposed to the sun. It may be observed that the bamboos serve a double purpose in that they provide shade, and, planted as they are on the lower edge of the walk, help to bind the soil and prevent the path from slipping away during the wet seasons. Less than half way up the walk a path branching off to the right will be noticed. This is the upper garden path which passes behind the various cacao plots and leads to the Curator's office.

From this point, taking the path leading up the hill, the top of the Morne Bruce cliff is reached in less than $\overline{5}$ minutes. Having reached the top after a strenuous climb, a few minutes will be well spent on the seat, from which a good view of the Gardens and surrounding country can be obtained. The large palm growing on the site of the old ruined Fort is Corypha umbraculifera, the Talipot palm of Ceylon.

Planted along the edge of the cliff are several trees of the Flamboyante, Poinciana regia, interplanted with Cassia Fistula, both of which make a fine show in the flowering season. The latter is known locally as "Cass." The medicinal value of the pods has been referred to elsewhere. Several vernacular names have been given to this tree in India and Ceylon where it is a native: Indian Laburnum being the most appropriate to English ears owing to the resemblance of its yellow flowers to those of the well-known Laburnum of cooler regions.

Proceeding for some distance along the path a lime nursery of some 2 acres in extent will be noted on the left. Close by is a collection of Australian Gum trees, Eucalyptus $s p p$. established some years ago from seeds imported from Australia. Prior to the hurricanes of 1915 and 1916 the collection comprised some seventy-two species, but many of 
these were destroyed as a result of these tropical disturbances, and the number of species now remaining does not exceed fifty. These Eucalypts have been kept under observation with $a^{\circ}$ view to finding quick growing trees suitable for fuel purposes, and adapted to local climatic conditions. Several of the species appear to thrive here in spite of the heavy rainfall and exposure to wind. Unfortunately they do not produce seed freely or regularly, therefore, to maintain a supply of nursery plants, it would be necessary to import seed at regular intervals.

The path now leads under the shade of a row of Saman trees-interplanted with which are specimens of a handsome palm, Phoenix reclinata-to the corner, where it joins with the public road which is the other route from Roseau.

Take the turning to the left and proceed as far as the avenue planted with date and coco nut palms. It will be observed that the trunks of the former, like those of many other palms of similar habit, make fine natural ferneries.

The plot of land on the left is about 2 acres in extent and contains batches of various plants, including: Paradise nut, Lecythis Zabucajo; Para Rubber, Hevea brasiliensis; Central American Rubber, Castilloa elastica; Camphor; Spineless Limes; and the Mexican Apple, Casimiroa edulis. The fruits of the latter somewhat resemble an English apple in size and appearance, and have a very pleasant flavour. Though the fruit itself is edible, the seeds, which are used in medicine in Mexico, are poisonous.

After leaving the avenue of date and coco-nut palms follow the road leading through the pasture. The four long buildings here situated are old military barracks. In the early days of the Agricultural Department these buildings were used as an Agricultural School; as many as twenty-five pupils being then under training. Pedigree animals were kept for stud purposes, and part of the boys training consisted in the care of these, as well as bee-keeping, vegetable gardening, and general agricultural routine work. From this point onwards there is little to note until the Lime Experiment Station is reached some 300 yards further along the road. 


\section{Lime EXPERIMENT StATION.}

Originally, the land now occupied by the Experiment Station was nothing better than a waste piece of ground, which, though owned by the Government, became generally known as the "free lands " where the poorer people of Roseau were at liberty to make gardens. The continuous cropping of this piece of land, without any return being made in the shape of manure, eventually resulted in an impoverished condition of the soil, and gradually the ground was abandoned and allowed to go to bush. Certain parts which had been planted in limes by the boys of the Reformatory School at the Morne in the year 1893 shared the same fate. This condition continued until 1913, the year the Agricultural Department took over what is now the Experiment Station. IVith these few facts concerning the original condition of the land, the visitor will be able to appreciate the extent of the improvement which has resulted from proper care and attention having been given in regard to manurial treatment and general cultivation.

The area of the Lime Experiment Station is approximately 65 acres about half of which is under cultivation, the remainder being bush land of doubtful agricultural value. Of the land under cultivation, 22 acres are planted in limes; 9 acres in coco-nuts; one acre in grape fruits and oranges; and about $1 \frac{1}{2}$ acres are devoted to mulch plots; Shea Butter, Butyrospermum Parkii; and Camphor. Camphor has also been planted in wind-breaks which may be seen at the lower end of the valley.

The Experiment Station, as far as limes are concerned, commences on the corner at the foot of the road leading from Morne Bruce to the valley. The plot of coco-nuts close by is situated on the eastern boundary. By turning to the right and following the public road to Roseau, the various lime plots may be seen on either side.

On the corner will be found a plot of the true Camphor bearing trees. Several experimental distillations have been made from the leaves and twigs taken from these specimens. Another batch of camphor trees will be observed on the opposite side of the road behind No. 1 Lime plot. 
The wind-break running parallel with plot 1 is planted with Poix Doux, Inga laurina, a tree largely used in the Island to give protection to cacao and lime cultivations from the wind. Another of the same kind of wind-break is planted at the back of the lime plots on the right, commencing just behind the camphor plot and extending for some distance along the slope.

As all the principal plots bear a board showing the manurial treatment given to each, a description of the experiments may serve as a sufficient guide to enable the visitor to follow the line of work which is here undertaken in the interests of planters.

The principal manurial experiments now being conducted in this valley were commenced in 1917, and take the place of those started in 1913 which were considerably disorganized as a result of the damage wrought by the hurricanes of 1915 and 1916.

The present experiments are conducted in 3 series known as original, duplicate and triplicate series, each of which consists of five plots. Each plot is approximately $\frac{1}{4}$-acre in extent and contains twenty-four trees which are planted at $20 \times 20 \mathrm{ft}$. apart. The trees planted in 1913 which were included in the original experiments came through the hurricanes undamaged and now form series 1 and 2 . Series 3 consists of old trees planted in 1893. The object in including old trees in the experiments is to ascertain to what degree old trees are able to respond to the application of fertilizers.

The following treatment given to the 5 plots in series 1 is repeated in series 2 and 3 .

Plot 1 Complete manure.

do. 2 Control.

do. 3 Mulch.

do. 4 Nitrogen and Phosphates.

do. 5 Nitrogen and Potash.

By repeating the same treatment three times a comparison of the results obtained from each series allows of a more accurate conclusion being drawn as to the true value of the manures employed. 
All the plots in the 3 series, with the exception of two which are lower down on the right, will be found on the lefthand side of the road. On the right-hand side of the road are four plots of lime trees which receive a complete manure. Two of these plots consist of the ordinary spiny type and one of the spineless variety, both kinds being budded on the sour orange stock. The spineless variety was discovered many years ago on the Shawford Estate, and following its discovery was planted on several other estates throughout the Island. In spite of the advantage it possesses over the spiny type in being unarmed with spines, it is a less prolific bearer, and for this reason has not been extensively planted. The fruit of the spineless variety though small, possesses a very thin rind, an abundance of clear juice, and contains fewer seeds than the ordinary kind; but these good points do not appear to outweigh its shy-bearing qualities.

At the end of these plots stands the old military cemetery, in front of which several trees of Shea Butter, Butyrospermum Parkii, are growing. The Shea Butter tree has been mentioned elsewhere in this guide. It is a slow growing tree and is a native of Africa. Continuing along the road other lime plots under manurial experiments will be found lower down the valley. These experiments, like those already noted, are conducted in 3 series. Each series consists of three $\frac{1}{1}$ acre plots. The following treatment given to series 1 , is repeated in series 2 and 3.

The plots are numbered 16 to 24 .

$$
\begin{aligned}
& \text { Plot 16, } 500 \mathrm{lb} \text {. Mixed Fertilizer. } \\
\text { Series } 1 & \text { Plot 17, Control (no manure). } \\
& \text { Plot 18, 1,000 lb. Mixed Fertilizer. }
\end{aligned}
$$

In addition to the fertilizers, each plot, with the exception of the controls, receives an application of mulch at the rate of $2 \frac{1}{2}$ tons per acre.

Mulch, consisting of the leaves and succulent twigs of various leguminous plants, as well as cut grass, bush, canetops, or any other vegetable material, forms an essen ial and valuable addition to tropical soils. Mulch not only gives the soil the necessary protection from the strong rays of the sun, 
it also improves its physical character ; adding as it does to the humus content of the soil, and thereby increasing the power of the soil to retain moisture and manurial constituents.

Most of the mulch material is grown on plots of land near the lime cultivation. A fairly large piece of ground used for this purpose will be noticed near plot 22. The tall trees growing on this land are specimens of the Honduras Mahogany, Swietenia macrophylla.

At the foot of this slope are several specimens of the oil palm, Elaeis guineensis, of West Tropical Africa. The fruits of this palm yield the valuable oils of commerce known respectively as Palm oil and Palm Kernel oil. The former obtained from the outer fleshy fibrous layer of the fruit, is used chiefly in the manufacture of soaps and candles; while the latter, obtained from the kernel, is used for making margarine, and for other purposes.

In addition to the lime cultivation under manurial experiments, other areas planted elsewhere with this crop will be observed. These areas, several of which are suitable as experiment plots will serve in future experiments as occasion may demand. In the meantime such cultivation is a source of financial support to the Department, the whole crop being sold to Messrs. L. Rose \& Co., Ltd, of the Bath Estate.

An outstanding feature of most of the plots is the system of drainage. The contour drains on the steep slopes are of special interest. For the information of visitors who may not know of the value and utility of contour drains in parts of the tropics where heavy rains are experienced, it will be as well to mention that the chief purpose for which such drains are made is to prevent the rush of water down the slopes, and so preserve the loose surface soil and manurial constituents from being carried away. In the absence of contour drains, much of this material is eventually washed down during successive heavy showers on to the lower part of the slope, and into the valleys and ravines where it is lost to the cultivation. On steep slopes where the precaution in supplying contour drains is neglected, there soon appears a striking difference between the colour of the leaves of the plants at the top, and the leaves 
of those at the foot of the slope: the plants at the top exhibiting a yellow and sickly appearance, whilst those at the bottom are usually of a dark green and healthy appearance.

The collection of grape fruit trees on the left hand side of the road comprise the following varieties:-Walters grape fruit, Silver Cluster, Duncan, Marsh's seedless, Jamaica and Triumph.

Behind these are a few choice varieties of orange trees, such as: Pineapple, Ruby blood orange, Boon's Early, King mandarin and Satsuma mandarin. These were planted for the selection of the best kinds and for the supply of bud wood for budding purposes.

It only remains to be stated that development work in connexion with limes and other plants is being steadily continued. By the time this is completed, it is hoped a factory will be erected for dealing with what will be a large crop of limes in order that experiment and research work in the manufacture of lime products may be undertaken by the staff of the Department. Such investigations are important and necessary, and are the natural outcome of cultural and manurial experiments in the field.

To show the way to improvements and to increase the efficiency of the lime industry as a whole, is the main aim of the Experiment Station. It is the only way of meeting successfully the keen competition which is now beginning to face the lime planter of Dominica. 



\section{INDEX,}

A.

PAGE.

Abeokuta Coffee (Coffea liberica var. Abeokuta)..

Aberia caffra

Acacia riparia

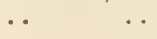

-sphaerocephala

$\cdots$

$\cdots$

Acalypha Wilkesiana

$\cdots$

18,43

Acanthophoenix Alexandrae ..

Acanthorhiza aculeata -rubra (palm)

Achras Spp. ..

.

.

33

6,41

41

23

22

10

Acoma (Sideroxylon floribundum)

Acrocomia sclerocarpa

- $\quad \cdots$

Adansonia digitata ...

.

15

36

Adenanthera

$\cdots$

.

Aechmea fulgens

$\cdots$

$\cdots$

African Mahogany (Khaya senegalensis)

Afzelia madagascariensis

s)

Agave Franzosinii

-.

..

Agaves

- rigida var. Sisalana

Akee (Blighia sapida)

Albizzia Lebbek

$$
\text { -lophantha .. }
$$

$\cdots$

..

-Moluccana ..

Aleurites triloba (Candle berry tree)

Allamanda violacea.

Alligator Cacao (Theobroma pentagona)

Allspice Tree (Pimenta officinalis) ..

\section{Aloes}

Alpinia Galanga

-nutans

Alstonia scholaris

Amherstia nobilis

Amyris balsamifera .

Anacardium excelsum

$$
\text { -occidentale }
$$

Anamirta cocculus ..

$$
\text { - surinamensis }
$$

Anchovy Pear (Grias cauliflora)

Andira inermis

Annatto (Bixa orellana)

Anodendron paniculatum

Anona Buchanani

$$
\text { -muricata }
$$

- recticulata

-squamosa

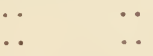

$\cdots$ 
ii.

Aralia Guilfoylei ..

A.-(Concluded.)

Page.

Araucaria Bidwilli . -brasiliensis

Ardisia Oliveri

Areca Aliciae (palm)

- catechu -glandiformis ..

Arenga Engleri --saccharifera ..

Aristolochia gigas ..

Artabotrys odoratissimus

Artocarpus incisa, var. seminifera -integrifolia

- Lakoocha

Assam Rubber Tree (Ficus elastica)

Astrocaryum Ayri ..

Atalantia monophylla

Attalea cohune

Averrhoa Bilimbi .. - Carambola

Avocado Pear (Persea gratissima)

Arundo donax (Giant reed)

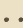

19,31

B.

Baba-ou-le (Dioscorea alata) ..

Bactris major (palm)

Baikiea Eminii

-insignis

Balata (Mimusops globosa)

B.

Balisier (Heliconia Bihai)

Balsam of Copaiba (Copaiba balsamifera) -Tolu (Myroxylon Toluifera)

Bamboo (Bambusa vulgaris)

- (Thyrsostachys siamensis)

- dwarf (Bambusa nana)

-spiny (Bambusa spinosa)

Bambusa nana (Dwarf bamboo)

-spinosa (spiny bamboo)

Baobab tree ( 4 dansonia digitata)

Barringtonia speciosa

Basser paln (Ianicaria saccifera)

Bassia latifoli.z

Bastard Cabbage Bark Tree (Andira inermis)

Bauhinia Galpini

-Petersiana

- picta

- purpurea .

-tomentos .

-variegataa

Bay tree (Pimenta acris)

Bead Tree (Adinanthera pavonina)

- Elaeocarpus Ganitrus)

Beaumontia grandiflora

..

Beilschmeidia lioxburghiana .. 
Ben, oil of (Moringa pterygosperma)

Bentinckia nicobarica

Berrya Ammonilla ..

6,15

Bertholetia excelsa . .

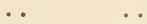

34

Betel Nut (Areca Catechu)

$\cdots$

Bignonia alliacea

Bilimbi (Averrhoa Bilimbi) ..

Bixa Orellana

Blighia sapida

Boehmeria tenacissima

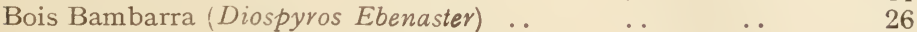

-Chandelle (Amyris balsamifera) ..

- Cotlette (Citherexylon quadrangulare)

. $\quad$.

-Diable (Licania hypoleuca)

-d'Inde (Pimenta acris) ..-

-D'Orme (Guazuma ulimfolia) ..

-Flot (Ochroma lagopus)

- Pain (Talauma plumieri)

-ravine (Calliandra tergemina)

-Vinette (Erythroxylon ovatum)

Bombax Malabaricum

Borassus flabelliformis (Palmyra palm)

Bougainvillaea glabra

$\begin{array}{ll}\text { - laterita } & \ldots \\ \text { - spectabilis } & \ldots \\ \text {-var. laterita } & \ldots \\ \text {-vars } & \ldots\end{array}$

Brachychiton acerifolium ...

.

$\begin{array}{lllll}\text { Brasil Nut (Bertholetia excelsa) } & \ldots & . & & \\ \text { Bread-and-Cheese tree (Pithecolobium ringius-cati) } & \ldots & 34 \\ \end{array}$

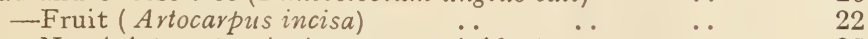

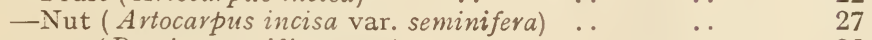

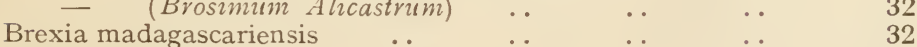

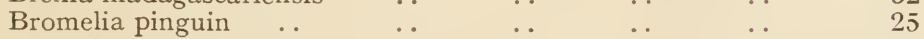

$\begin{array}{llllll}\text { Brosimum Alicastrum } & \ldots & \ldots & \ldots & \ldots & 32\end{array}$

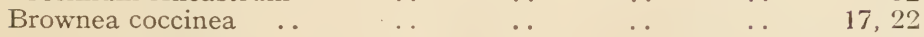

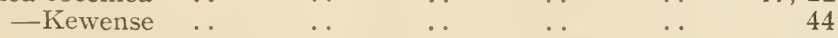

Brunfelsia americana

22

18,42

38

12

38

12

50

12

$\begin{array}{rrrrr}\text { Butter Nut (Caryocar nuciferum) } & \ldots & \ldots & \ldots & 27 \\ \text {-Tree (Pentadesma butyracea) } & \ldots & \ldots & 33\end{array}$

Butyrospermum Parkii

. $28,55,57$

Byrsonima spicata

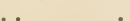


iv.

C.

Cacao, experiments with

Caconier (Ormosia dasycarpa)

Caesalpinia coriaria ..

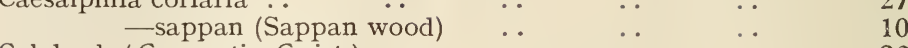

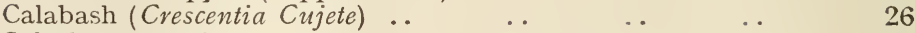

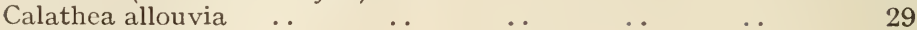

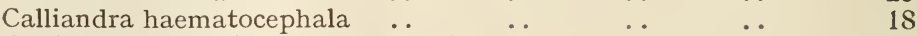

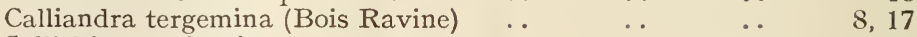

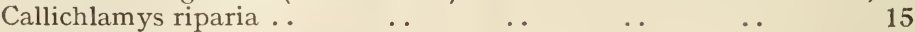

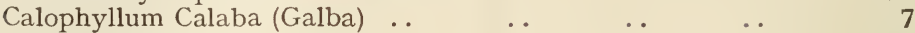

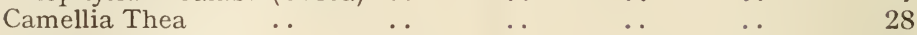

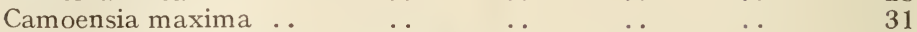

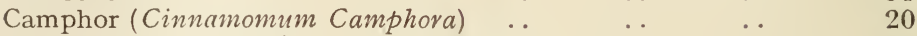

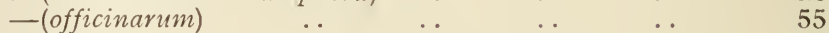

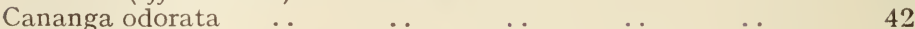

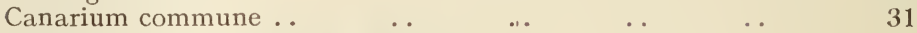

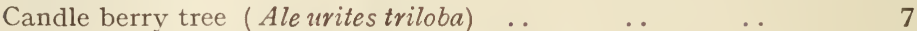

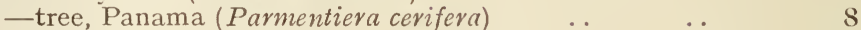

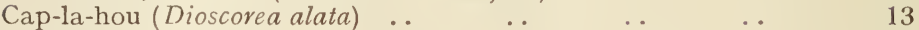

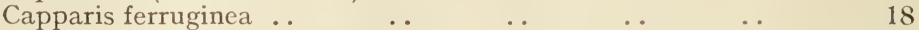

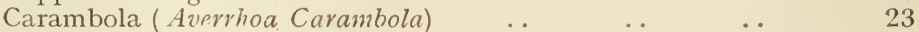

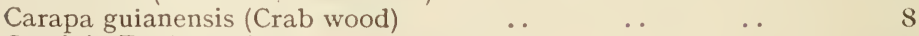

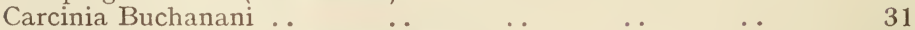

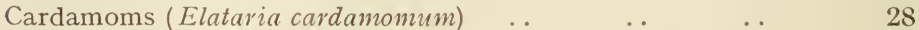

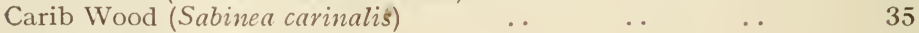

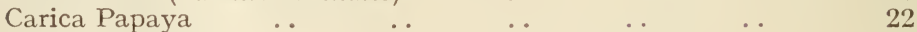

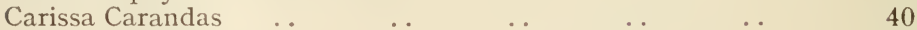

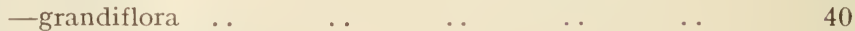

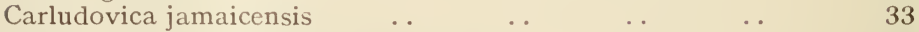

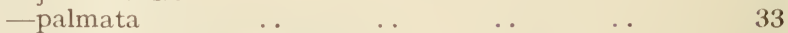

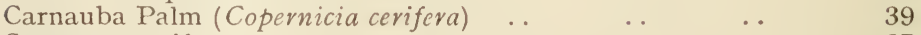

$\begin{array}{llllll}\text { Caryocar nuciferum } & \ldots & \ldots & \ldots & \ldots & 27\end{array}$

Caryota

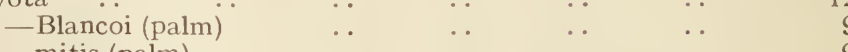

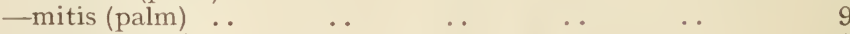

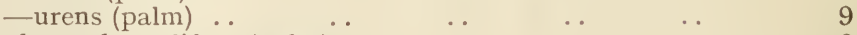

$\begin{array}{lllll}\text { Corypha umbraculifera }(\text { palm) } & \ldots & \ldots & \ldots & 6\end{array}$

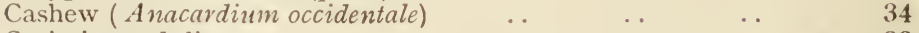

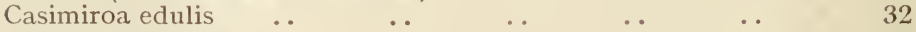

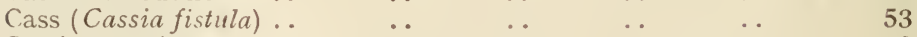

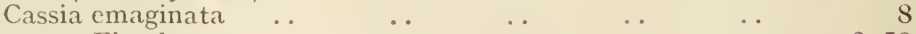

$\begin{array}{lllllll}\text {-Fistula } & \ldots & \ldots & \ldots & \ldots & \ldots & 6,53\end{array}$

$\begin{array}{lllllll}\text {-grandis } & \ldots & \ldots & \ldots & \ldots & \ldots & \text { S }\end{array}$

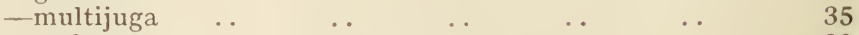

$\begin{array}{lllllll}\text { - nodosa } & \ldots & \ldots & \ldots & \ldots & \ldots & 39\end{array}$

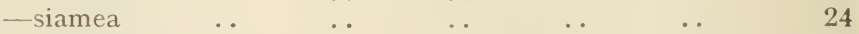

$\begin{array}{llllll}\text { - Sieberiana } & \ldots & \ldots & \ldots & \ldots & \ldots \\ \end{array}$

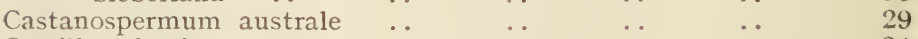

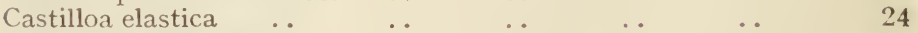

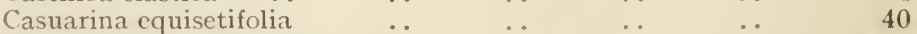

Catalpa longissima (French oak) $\quad \ldots \quad \ldots \quad \ldots \quad$ 8, 15, 17

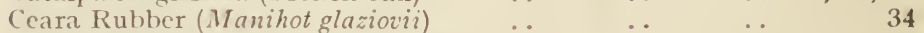

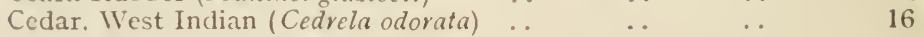


v.

Cedrela odorata

\section{C.-(Continued.)}

PAGE.

Cedron (Simaba cedron)

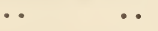

Celtis australis

Cephylostachyum pergracile ..

Cebrea Tanghin (Ordęal Nut) . .

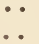

Cestrum diurnum

.

Champac (Michelia $\dot{\text { Champac) }}$..

Chaulmoogra oil

Cherry, Surinam (Eıgenia Micheli) - West Indian (Malgighia glabra)

Chicle Gum (Achras spp.)

Chloroxylon Swietenia

Chrysalidocarpus lutescens (palm)

Chrysobalanus Icaco

Chrysophyllum cainito

Cicca disticha

Cinnamomum brevifolium

$\cdots$

-Caniphora

.

-officinarum

.

\section{-Zeylanicum}

.

.

Cinnamon (Cinnamomum brevifolium)

Citharexylon quadrangulare

Citronella Grass (Cymbopogon Nardus)

Citrus Aurantium var. lusitanica

-decumana

- medica var. acida

$\ldots$
$\cdots$
$\cdots$
$\cdots$

Clausenobilis var. major

- Limetta

-Limonum

..

.

$\cdots$

.

$\cdots$

$\cdots$

$\cdots$

..

$\cdots$

Clavija ornata

Clerodendron Bakeri

-Eastatum

$\cdots$

$\cdots$

Clibadium Vargesii .

$\cdots$

Clove Tree (Eugenia caryophyllata)

Coca (Erythroxylon Coca)

Coccoloba latifolia

Cocculus Indicus

Cochlospermum Gossypium ..

Coco-de-mer (Lodoicea sechellarum)

Coco Plum (Chrysobalanus Icaco)

Coconut (Cocos nucifera)

Cocos plumosa

Coffee (Coffea arabica)

-Congo (Coffea robusta) ..

Coffea liberica

-robusta

Cohune Palm (Attalea cohune)

Cola Afzeli ..

$\cdots$

..

$\cdots$

..

.

.

$\cdots$

$\cdots$

$\cdots$

$\cdots$

$\cdots$

..

.

$\cdots$

$\cdots$

.

.

$7,11,42$

36

21

30

21

20

55

28

21

13

49

31,47

49

48

31,47

47

31

32

32

44

11

22 
vi.

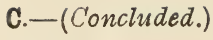

PAGE.

\begin{tabular}{|c|c|c|c|c|c|c|}
\hline olvillea racemosa & . & $\cdots$ & .. & .. & . & 43 \\
\hline Combretum laxum & .. & . & . & . & . & 21 \\
\hline Comocladia ilicifolia & .. & . & . & . & .. & 17 \\
\hline Congea tomentosa & . & . & . & . & .. & 21,23 \\
\hline Copaiba balsamifera & . & . & . & . & $\ldots$ & 31 \\
\hline Copaifera officinalis & $\ldots$ & . & . & .. & .. & 11 \\
\hline Corallita (Antigonon & leptopus) & .. & . & .. & $\cdots$ & 23 \\
\hline Cordia Gerascanthus & & .. & $\cdots$ & . & . & 13 \\
\hline -Sebestena & . & . & . & . & . & 28 \\
\hline orypha elata & . & .. & . & . & . & 40 \\
\hline -gebanga & . & . & . & . & . & 40 \\
\hline -umbraculife & era & $\ldots$ & $\because$ & . & . & $40,42,53$ \\
\hline \multicolumn{4}{|c|}{ Couroupita guianensis (Cannon ball tree) } & . & . & 12 \\
\hline Crabwood (Carapag & uianensis & & . & . & . & 8 \\
\hline Crataeva gynandra & . & . & . & . & . & 29 \\
\hline rescentia cucurbitin & & .. & . & . & . & 26 \\
\hline -Cujete & . & . & $\cdots$ & . & $\cdots$ & 26,27 \\
\hline Croton discolor & . & . & $\cdots$ & . & . & 43 \\
\hline —tiglium & $\cdots$ & .. & . & . & .. & 30 \\
\hline Cryptostegia grandif & lora & . & . & . & . & 15 \\
\hline Crysophyllum glabru & $\mathrm{um}$ & . & . & . & $\cdots$ & 25 \\
\hline -Miller & & . & . & . & . & 19 \\
\hline Cupressus glabra & . & $\ldots$ & . & . & - & 19 \\
\hline Custard Apple ( $A$ no & na reticul & lata) & . & . & . & 25 \\
\hline Cycas Seemanii & $\ldots$ & $\ldots$ & . & . & . & 19 \\
\hline ymbopogon citratu. & & . & .. & . & . & 49 \\
\hline -Nardus & & . & . & . & . & \\
\hline - Schoen & lanthus & .. & .. & .. & $\ldots$ & 49 \\
\hline
\end{tabular}

D.

Dalbergia lanclolaria. .

\begin{tabular}{|c|c|c|}
\hline . & . & 11 \\
\hline . & . & 11 \\
\hline . & $\cdots$ & 38 \\
\hline . & . & 35 \\
\hline . & .. & 29 \\
\hline . & .. & 35 \\
\hline . & . & 36 \\
\hline . & .. & 10 \\
\hline . & . & 43 \\
\hline . & . & 03 \\
\hline$\cdots$ & $\cdots$ & 17 \\
\hline . & $\cdots$ & 13 \\
\hline$\cdots$ & $\cdots$ & קר \\
\hline . & $\cdots$ & 26,32 \\
\hline$\cdots$ & . & \\
\hline$\cdots$ & . & 27 \\
\hline . & . & 41 \\
\hline . & . & 14 \\
\hline . & . & 11 \\
\hline$\cdots$ & $\cdots$ & 14,16 \\
\hline$\cdots$ & $\cdots$ & 28, \\
\hline
\end{tabular}


vii.

E.

Elaeis guineensis

Elaeocarpus Ganitrus (Bead tree)

Elaeodendron glaucum

Elemi (Canarium commine) ..

Elettaria Cardamomum

Emsall Gate

Encephalartos Hildebrantii ...

Entada polystachya..

Enterolobium cyclocarpum

Entrance Gates

Eriobotrya japonica . .

Erythrina senegalensis

Erythroxylon Coca ..

-ovatum

Eucalyptus collection

-corymbosa

- creba

- patentinervis

- tereticornis

-tesselaris

Eugenia caryophyllata

$\begin{array}{ll}\text { - cauliflora .. } \\ \text { - Jambolana .. } \\ \text { - lineata } & . . \\ \text { malacensis .. } \\ \text { - Micheli } & . \\ \text { - paniculata .. }\end{array}$

Euphorbia splendens

Euterpe edulis

Excoecaria Agallocha

Experiment Plots, Cacso

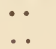

$\ldots$

..

.

.

.

.

$\cdots$

.

..

..

..

.

33,38
10
20
31
28
24
17
15
36
4
22,29
23
13,22
13
53
20
18
6
24
38
24
31
34
23
26
25
35
28
42
42
45

F.

Fagraea Zeylanica ..

Feijoa Sellowiana ..

Feronia Elephantum..

Ficus altissima

-Benjamina $\quad$.

- elastica $\quad$..

- Parcelli

-Vogelii

Filicium decipiens

Flacourtia Ramontchi

Flamboyante (Poinciana regia)

Frangipani (Plumieria alba) ..

French oak (Catalpa longissima)

Fruit Beal (Aegle Marmelos) ..

Funtumia africana

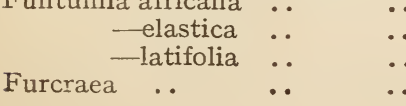

\begin{tabular}{|c|c|c|c|}
\hline . & . & $\ldots$ & 32 \\
\hline . & $\ldots$ & . & 32 \\
\hline . & .. & $\ldots$ & 31 \\
\hline$\ldots$ & . & .. & 14 \\
\hline . & .. & .. & \\
\hline .. & $\ldots$ & $\ldots$ & \\
\hline .. & $\ldots$ & $\ldots$ & \\
\hline . & . & .. & d. \\
\hline .. & . & .. & \\
\hline .. & . & . & \\
\hline . & .. & .. & \\
\hline . & . & . & 8,24 , \\
\hline . & .. & . & \\
\hline - & -. & . & \\
\hline .. & . & . & \\
\hline$\cdots$ & . & . & \\
\hline .. & .. & $\cdots$ & \\
\hline .. & . & . & \\
\hline . & & & \\
\hline
\end{tabular}


viii.

G.

Galba (Calophyllum Calaba)

Galphimia brasiliensis

. $\quad \ldots \quad \ldots$

Gamboge (Garcinia Morella) ••

..

Garcinia Indica

-Mangostana

-Morella

-oblongifolia

-Xanthochymus

Gardenia florida

.

.

..

.

$\cdots$

.

Garlic Pear (Crataeva gynandra)

Genip (Melicocca bijuga)

Ginger (Zingiber officinalis)

-Grass (Cymbopogon Schoenanthus)

-Lily (Hedychium coronarium)

Givotia rottleriformis

Gliricidia maculata ..

Gmelina arborea

$$
\text { -Hystrix }
$$

Golden Apple (Spondias Borbonica) -.

Gooseberry, West Indian (Pereskia aculeata)

Governor Plum (Flacouvtia Ramontchi)

Granadilla (Passiflora quadrangularis) ..

Grape-fruit (Citrus decumana var.) ..

- collection of varieties

Grevillea robusta ..

\section{$\cdots$}

Grias cauliflora

Guaiacum officinale . .

Guava (Psidium sp.)

-Berry (Eugenia lineata)

Guazuma ulmifolia

Guinea Grass (Panicum maximum)

.. $\quad$.

$\cdots$

.

.

..

..

$\bullet$

H.

Hardwickia pinnata . .

Hedychium coronarium

Heliconia Bihai

Heritiera macrophylla

Hernandia sonora ..

Hibiscus Waimcae ..

Hirtella triandra

History of the Gardens

Holmskioldia sanguinea

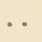

..

Horse Tamarind or Wild Tamarind (Leucaena glauca) .. 13

Hunterman's Nut (Omphalea megacarpa) $\quad \ldots . \quad \ldots .39$

Hymenea Courbaril (West Indian Locust) $\quad$. . $\quad$. . 12

Hyophorbe amaricaulis 
ix.

\section{I.-(Conclvoded.)}

¿xora Amboinica ..

$\begin{array}{ll}\ldots & \ldots \\ \ldots & \ldots \\ \ldots & \ldots \\ \ldots & \ldots\end{array}$

-coccinea ..

-lutea

-macrothyrsa ..

J.

Jaborandi (Pilocarpus microphyllhss) -pennatifolius

Jaboticaba (Mycaria cauliflora)

Jacaranda cerulea

- mimosaefolia

Jamoon (Eugenia paniculata)..

Jatropha Curcas -multifida .

Java Plum (Eugenia Jambolana)

Jequie Manicoba (Manihot dichotoma)

Jujube (Zizyphus Jujuba) . .

Juniperus Bermudiana

- pachyphloea

Jupati Palm (Raphia taedigera)

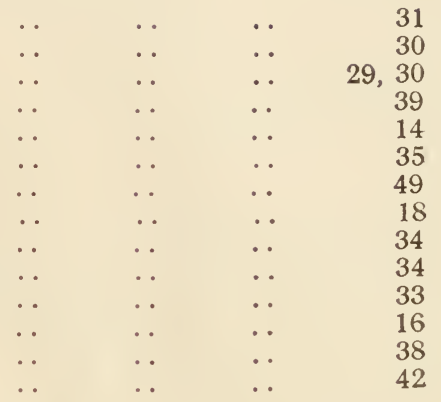

K.

Kaffir Orange (Strychnos spinosa)

Kaki Plum (Diospyros Kaki) ..

Kapok (Eriodendron anfractıosum)

Kei Apple (Aberia caffra) ..

Khaya senegalensis .

Kigelia pinnata

Kleinhovea hospita ..

Kokum Butter (Garcinia Indica)

Kola Nut (Cola vera)

Kuteera Gum

Kydia calycina

$\begin{array}{llll}. & \ldots & \ldots & 32 \\ . & \ldots & \ldots & 28 \\ . & \ldots & \ldots & 46 \\ . & \ldots & \ldots & 37 \\ . & \ldots & \ldots & 17 \\ . & \ldots & \ldots & 43 \\ . & \ldots & \ldots & 31 \\ . & \ldots & \ldots & 50 \\ . & \ldots & \ldots & 23 \\ . & \ldots & \ldots & 41\end{array}$

Labramia Bogeri

Ladoicea sechellarum

Lagerstroemia flos-reginae -parviflora

Lansium domesticum

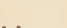

Leucaena glauca

Liberian Coffee (Coffea liberica)

Licania hypoleuca 
$\mathrm{x}$.

L.-(Concluded.)

PAGE.

Lime Experiment Station

var, acida)

55

-Spineless (Citrus medica var. acida)

Limonia acidissima ..

..

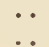

Litchi (Nephelium Litchi) .. $\quad$..

Livistona chinensis .. $\quad$.. $\quad$..

-olivaeformis

Logwood (Haematoxylon campechianum)

Lonchocarpus cyanescens -violaceus

..

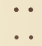

Loquat (Eriobotrya japonica) ..

Lucuma mammosa .. -multiflora . .

Lysidice rhodostegia

Mabola (Diospyros discolor)

$$
\cdots
$$

$\cdots$

$\cdots$

$\cdots$

$\cdots$

.

M.

Macadamia ternifolia

Macassar Oil Tree (Schleichera trijuga) ..

Mahogany, Honduras (Swietenia macrophylla) -(Swietenia Mahagoni)

Mahwa Tree (Bassia latifolia)

Main Gate - to Curator's Office

Malay Apple (Eugenia cauliflora)

$$
\text { -malaccensis }
$$

Male Bamboo (Dendrocalamus strictus) .

Malpighia glabra

Mammea americana. .

Mammee Apple (Mammea americana)

Mandarin (Citrus nobilis)

Mangifera indica

$$
\text { -sylvatica .. }
$$

Mango (Mangifera indica)

Mangosteen (Garcinia mangostana)

Manicaria saccifera (Bussu palm)

Nanihot dichotoma ..

$$
\begin{array}{lll}
\text {-glaziovii } & \cdots & \cdots
\end{array}
$$

Manila Hemp (Musa textilis) ..

Manuriłl Experiments with Cacao

$$
\text { -Plots, Limes }
$$

Marking nut tree (Semecarpus Anacardium)

Marmalade Plum (Lucuma mammosa) ..

Martinezia Caryotaefolia

Corallina

$$
\text { flexuosa }
$$

Melaleuca sp.

Melocactus communis

Melocanna bambusoides

Nichelia Champaca ..

Mimusops Elengi ..

$$
\text { - globosa } \ldots
$$

.$$
\text { -Schimperi . }
$$

Monkey Cacao (Theobroma angustifolia)

$$
\text { . }
$$$$
\text { . }
$$$$
\text { .. }
$$$$
\text { .. }
$$$$
\text { . }
$$

.

$$
\begin{array}{ll}
\cdots & \cdots \\
\cdots & \ldots
\end{array}
$$

Monodora tenuifolia ..

\section{8}

11

29,30

17

17

34

12,34

22,29

27

25

34

38

6,58

37

30

5

31

26

36

31

22

22

31

34,44

33

34,44

27 
xi.

M.-(Concluded.)

PAge.

Monstera

..

$\cdots$

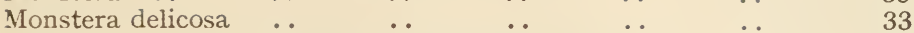

Moreton Bay Ash (Eucalyptus tesselaris) $\quad$.. $\quad$.. $\quad 38$

- Chestnut (Castanospermum australe) .. 29

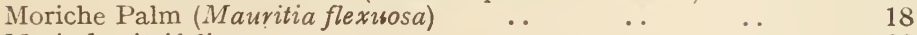

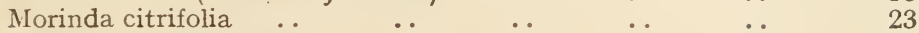

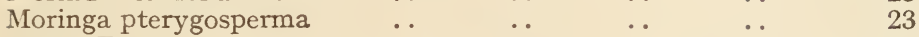

$\begin{array}{llllll}\text { Morne Bruce } & \ldots & \ldots & \ldots & \ldots & 36,52\end{array}$

$\begin{array}{llllll}\text { Morus alba } & \ldots & \ldots & \ldots & \ldots & 18\end{array}$

$\begin{array}{llllll}\text { Muehlenbeckia platyclada } & \ldots & \ldots & \ldots & \ldots & 40\end{array}$

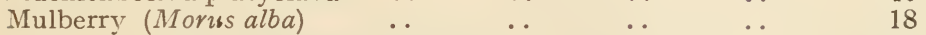

-Indian (Morinda citrifolia) . $\quad \ldots \quad \ldots \quad \ldots 23$

Murraya exotica

Musa textilis

Myricaria

Myristica fragrans $\quad \ldots \quad \ldots$

Myrobolans (Terminalia belerica)

Myrospermum frutescens

Myroxylon sonsonatense

-Toluifera

N.

Napoleona Miersii

Negro Peach (Sarcocephalus esculentus)

Nephelium lappaceum

$$
\text { - Litchi }
$$

Nerium Oleander ..

Norantea guianensis . .

Noronia emarginata ..

Nurseries .. .

$$
\text { -also work of }
$$

Nutmeg (Myristica fragrans)

$\begin{array}{ll}\cdots & \\ \ldots & \\ \cdots & \\ \cdots & \\ \cdots & \\ \cdots & \\ \cdots & \\ \cdots & \\ \cdots & \end{array}$

$\begin{array}{ll}\ldots & \ldots \\ \ldots & \ldots \\ \ldots & \ldots \\ \ldots & \ldots \\ \ldots & \ldots \\ \ldots & \ldots \\ \ldots & \ldots \\ \ldots & \ldots \\ \ldots & \end{array}$

11

14

30

29,30

29

18

12

39

20

51

49

0.

Objects of the Gardens

Ochroma Lagopus . .

Odontadenia speciosa

Office

-and Laboratory

Oil Palm (Elaeis guineensis)

Oleander (Nerium Oleander) .

Omphalea megacarpa

Opuntia -triandra ..

Ordeal nut ( $\dot{\text { Cerbrea }}$ Tanghin)..

Oreodoxa oleracea (Cabbage palm)

Ormosia dasycarpa ..

Oroxylon indicum

Otaheite Gooseberry (Sicca disticha)

Owenia cepiodora

$\cdots$ 
xii.

P.

PAGE.

Pachira aquatica

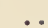

Pain d'Epices

. $\quad$.

Palmyra palm (Borassus flabelliformis)

Panama hats

Pandanus Baptistii ...

- graminifolius

-luzonensis

-pacificus ..

- Sanderiana

$\cdots$

-utilis (Screw pine) ..

Panicum maximum ..

Papaw (Carica papaya)

Paradise Nut (Lecythis Zabucajo)

Parkia africana

Parkinsonia aculeata

Parmentiera cerifera (Candle tree, Panama)

Passiflora quadrangularis

Pelican Flower (Avistolochia gigas)

Peltophorum africanum

-ferrugineum

-Linnaei

Pencil Cedar (Juniperus Bermidiana) ..

Pentadesma butyracea

Pereskia aculeata

..

$\cdots$

Persea gratissima ..

Phoenix acaulis

-canariensis...

—dactylifera ..

-humilis var. Roebelini

-reclinata

-rupicola (palm)

Physic Nut (Jatropha Curcas)

Phytelephas macrocarpa (Ivory palm) .

Piassava Fibre (Raphia vinifera) ..

Pilocarpus microphyllus

$$
\begin{aligned}
& \text {-sp. } \\
& \text {-pennatifolius } \\
& \text {-racemosus }
\end{aligned}
$$

Pimenta acris

一officinalis

Pinanga Kunlii

Pinus Bahamensis $\quad \ldots$

$$
\text { - longifolia }
$$

Piper Betle

$$
\text { -longum }
$$

Pepper (Piper longum)

Piptadenia peregrina

Piscidea Erythrina ..

Pitcairnia coccinea ..

Pithecolobium Berterianum 
xiii.

P.-(Conclusded.)

Plants distributed, number annually .

Platymiscium platystachyum ..

Pleomele fragrans -ugandensis

$\cdots$

Plumieria alba

$\cdots$

$\because$

Podocarpus sp.

.

Poinciana regia (Flamboyante)

Pois-doux (Inga larsvina)

. $\quad$.

10

$8,24,53$

Pomegranate (Prnica granatum)

35,56

Pomelo (Citrus decumana) ..

$\cdots$

Pongamia glabra

Portugal Orange (Citrus Aurantium var. lusitanica)

Posoqueria latifolia ..

.. $\quad$.

Potato Tree (Solanum macranthum)

Poutaria suavis

Premna odorata

Pritchardia pacifica ..

Pseudospondias macrocarpa .

Psidium Guava

Pterocarpus Marsupium

$$
\text { -Rohrii .. }
$$

Ptychoraphis augusta

Ptychosperma Macarthuri

Purple Wreath (Petrea volıbilis)

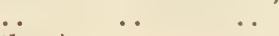

$\therefore \quad \cdots$

.. $\quad .$.

. $\quad \cdots$

. $\quad$.

. $\quad$.

.. $\quad$.

. $\quad$.

. $\quad$..

.. $\quad$.

.. $\quad$.

47

38

31,47

24

37

29,30

7

42

35

25

32

7,33

43

15

Q.

Quebrachia Lorentzii

Oueen of Flowers (Lagerstroemia Flos-reginae) $\cdots$

Queensland Nut (Macadamia ternifolia)

Quisqualis indica

$\cdots$

R.

Rainfall and Climate

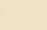

26,40

44

30

15,16

Rambutan (Nephelium lappaceum) ...

Ramie (Boehmeria tenacissima)

Randia maculata

-Mussaenda

Raphia pedunculata ..

-taedigera $\quad$.

Raphis flabelliformis..

Ravenala Guianensis

$$
\text { -Madagascariensis }
$$

$\cdots$

Reed, Giant (Avundo donax)

Resinier Grande Feuille (Coccoloba latifolia)

Rheedia edulis

$\cdots$

$\because$

44

21

41

42

42,43

42

42

Rhyncosia Wallichia

Roble Tree (Platymiscium platystachyum)

Rondeletia speciosa .. 
xiv.

R.-(Concluded.)

PAgE.

Roucou (Bixa orellana)

$\begin{array}{ll}\ldots & \ldots \\ \cdots & \cdots \\ \cdots & \cdots \\ \cdots & \cdots \\ \ldots & \cdots\end{array}$

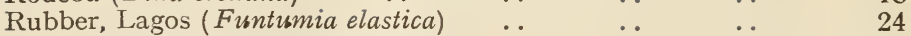

$\begin{array}{lllll}\text { - Mexican (Castilloa elastica) } & \text {. } & \text {. } & \text {. } & 24\end{array}$

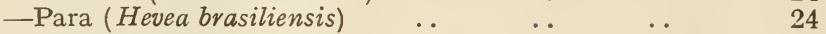

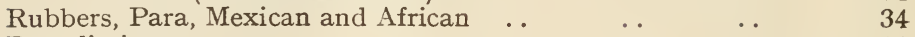

$\begin{array}{lllllll}\text { Russelia juncea } & \ldots & \ldots & \ldots & \ldots & \ldots & 11\end{array}$

S.

Sabinea carinalis

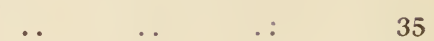

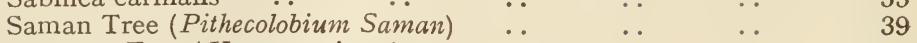

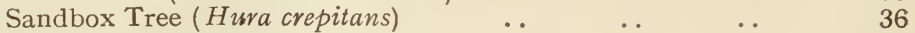

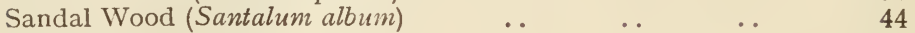

$\begin{array}{llllll}\text { Sandoricum indicum } & \ldots & \ldots & \ldots & \ldots & 39\end{array}$

$\begin{array}{lllllll}\text { Sansevieria } & \ldots & \ldots & \ldots & \ldots & \ldots & 11,22\end{array}$

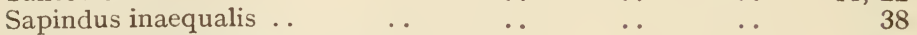

$\begin{array}{llllll}\text { Sapium aucuparium .. } & \ldots & \ldots & \ldots & \ldots & 36\end{array}$

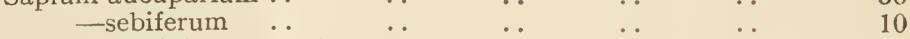

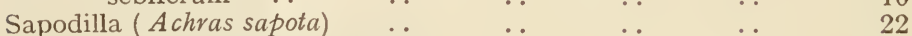

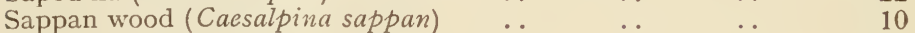

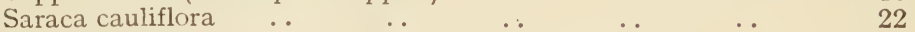

$\begin{array}{llllll}\text {-indica } & . & . & & & \\ \end{array}$

$\begin{array}{llllll}\text { Sarcocephalus cordatus } & \ldots & \ldots & \ldots & \ldots & 19\end{array}$

$\begin{array}{llllll}\text { esculentus } & \ldots & \ldots & \ldots & \ldots & 14,19\end{array}$

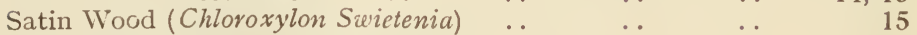

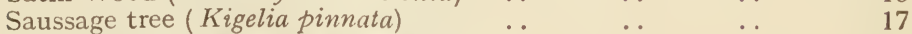

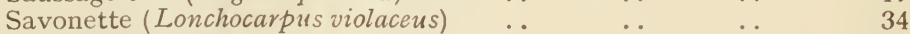

$\begin{array}{lllllll}\text { Scheelea excelsa } & \ldots & \ldots & \ldots & \ldots & \ldots & 6,38\end{array}$

$\begin{array}{llllll}\text { Schinus terebinthifolius } & \ldots & \ldots & \ldots & \ldots & 34\end{array}$

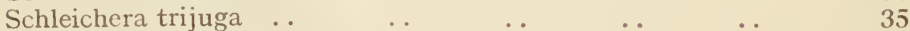

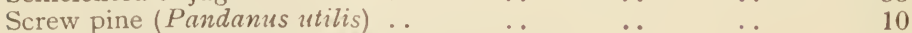

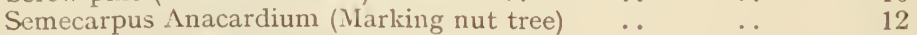

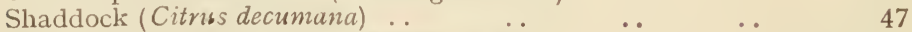

Shea Butter Tree (Butyrospermım Parkii) _. $\quad$. 2 28, 55, 57

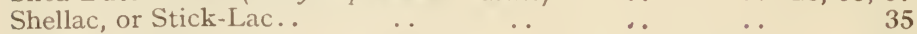

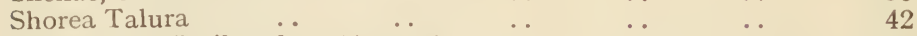

$\begin{array}{lllll}\text { Sideroxylon floribundum (Acoma) } & \ldots & \ldots & \ldots & 10\end{array}$

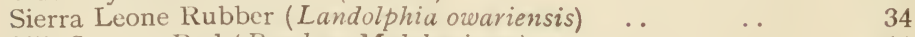

Silk Cotton, Red (Bombax Malabaricum) N $\quad$.. 41

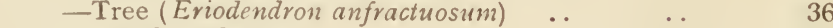

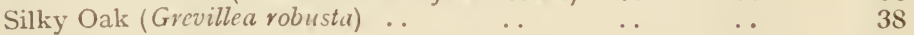

$\begin{array}{lllllll}\text { Simaba Cedron } & \ldots & \ldots & \ldots & \ldots & \ldots & 29\end{array}$

$\begin{array}{lllllll}\text { Simaruba amara } & \ldots & \ldots & \ldots & \ldots & \ldots & 15\end{array}$

$\begin{array}{lllllll}\text { Sisal Hemp } & \ldots & \ldots & \ldots & \ldots & \ldots & 32\end{array}$

$\begin{array}{lllll}\text { Situation and extent of Gardens } & \ldots & \ldots & \ldots & 2\end{array}$

Soapberry Tree (Sapindus inasqualis)

$\begin{array}{llllll}\text { Solanum macranthum } & \ldots & \ldots & \ldots & \ldots & 37\end{array}$

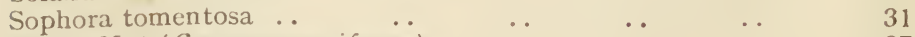

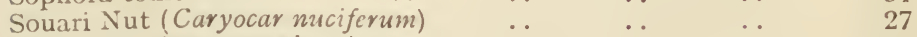

$\begin{array}{llllll}\text { Sour Sop (Anona inuricata) } & \ldots & \ldots & \ldots & \ldots & 25\end{array}$

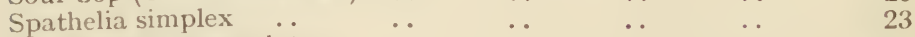

$\begin{array}{llllll}\text { Spathodea campanulata } & \ldots & \ldots & \ldots & \ldots & 7,37\end{array}$

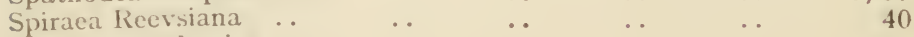

$\begin{array}{llllll}\text { Spondias Borbonica .. } & \ldots & \ldots & \ldots & \ldots & 23\end{array}$ 
$\mathrm{xv}$.

Stapelia sp...

S.-(Conclusded.)

PAGE。

Star Apple. -Plum (Crysophyllum glabrum)

Sterculia alata -carthaginensis

- foetida

Steriphoma paradoxa

Stevensonia grandifolia

Streblus asper

Strophanthus dichotomus

$$
\begin{aligned}
& \text { - gratus } \\
& \text { - Jackianus } \\
& \text { - Preusii }
\end{aligned}
$$

Strychnos spinosa

Sugar Apple (Anona squammosa)

- Cane (Saccharum officinarum)

- Palm (Arenga saccharifera)

Swartzia grandiflora

Sweet Lime (Citrus medica var. Limetta)

Swietenia Macrophylla (Honduras mahogany) -Mahagoni

Syncarpia laurifolia . .

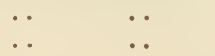

T.

Tabebuia leucoxylon. .

-pentaphylla

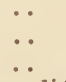

Talipot Palm (Corypha umbraculifera) .

Tamarind (Tamarindus indica)

Tea (Camellia Thea)

Teak Tree (Tectona grandis) ..

Tecoma serratifolia ..

$$
\begin{aligned}
& \text { - spectabilis } \\
& \text {-stans }
\end{aligned}
$$

Tectona grandis

Tendre Acailloux (Piptadenia peregrina)

Terminalia Arjuna

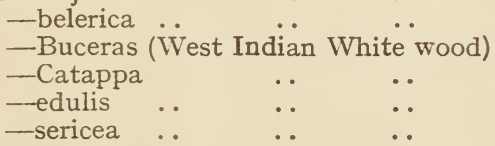

Theobroma bicolor ..

$$
\text { -pentagona }
$$

Thevetia nerifolia

$\cdots$
$\cdots$
$\cdots$
$\cdots$
$\cdots$
$\cdots$
$\cdots$
$\cdots$
$\cdots$
$\cdots$
$\cdots$

$\because$
$\because$
$\therefore$
$\because$
$\because$
$\because$
$\because$
$\because$
$\because$
$\because$
$\because$

\section{Thrinax Morrisii}

-parviflora (palm)

Thunbergia erecta

$$
\text { -grandiflora }
$$

.. 
xvi.

\section{T.-(Concluded.)}

PAGE.

Trachylobium verrucosum

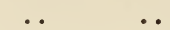

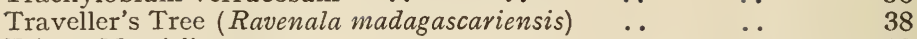

Trinax Morrisii

Triplaris surinamensis

12

38

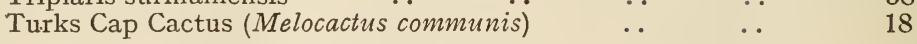

U.

Uapaca Kirkii

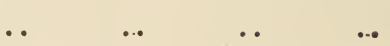

V.

Vangueria edulis $\quad \ldots \quad \quad \ldots$

Vanilla planifolia $\quad \ldots \quad$..

- - Vompona (Vanilla planifolia) $\quad$..

Vegetation, general features of the

Verschaffeltia splendida

Vetiver (Vetiveria Zizanioides)

Villebrunea integrifolia

Vitex divaricata

Voa-Vanga (Vangueria edulis)

$\begin{array}{lllr}\ldots & \ldots & \ldots & 28 \\ \ldots & \ldots & \ldots & 49 \\ \ldots & \ldots & \ldots & 49 \\ \ldots & \ldots & \ldots & 49 \\ \ldots & \ldots & \ldots & 3 \\ \ldots & \ldots & \ldots & 33 \\ \ldots & \ldots & \ldots & 22 \\ \ldots & \ldots & \ldots & 34 \\ \ldots & \ldots & \ldots & 28\end{array}$

W.

Wampi (Clausena Wampi)

Washingtonia filifera (palm) ..

Wine Palm (Raphia vinifera) ...

Woman's Tonguc (Albizzia Lebbek)

Wood Apple (Feronia Elephantum)

Wormia Burdidgei

Y.

Ylang-ylang (Cananga odorata)

Yokewood (Catalpa longissima)

Yucca aloifolia

-gloriosa

$\begin{array}{lllr}\ldots & \ldots & \ldots & 32 \\ \ldots & \ldots & \ldots & 7 \\ \cdots & \ldots & \ldots & 33 \\ \ldots & \ldots & \ldots & 42 \\ \ldots & \ldots & \ldots & 35 \\ \cdots & \ldots & \ldots & 31 \\ \cdots & \ldots & \ldots & 32\end{array}$

Z

Zamia sp.

Zingiber officinalis $\cdots$

Zizyphus Jujuba

$\begin{array}{llll}\ldots & \ldots & \ldots & 42 \\ \ldots & \ldots & \ldots & 17 \\ \ldots & \ldots & \ldots & 25 \\ \ldots & \ldots & \ldots & 32\end{array}$


